\title{
PATHOLOGICAL CHANGES IN 37 HUMAN RENAL HOMOTRANSPLANTS TREATED WTH IMMUNOSUPPRESSIVE DRUGS
}

K. A. PORTER, M.D., D.SC., M.C.Path.

T. L. MARCHIORO, M.D.

AND

T. E. STARZL, Ph.D., M.D.

From the Department of Pathology, St Mary's Hospital, London, and the Department of Surgery, University of Colorado Medical Center, Denver, Colorado

\author{
REPRINTED FROM THE \\ BRTIISH JOURNAL OF UROLOGY \\ (Vol. XXXVII, No. 3) \\ JUNE 1965
}




\title{
PATHOLOGICAL CHANGES IN 37 HUMAN RENAL HOMOTRANSPLANTS TREATED WTTH IMMUNOSUPPRESSIVE DRUGS
}

\author{
By K. A. Porter, M.D., D.Sc., M.C.Path., T. L. Marchioro, M.D. \\ and T. E. Starzl, Ph.D., M.D. \\ From the Department of Pathology, St Mary's Hospital, London, and the Department of Surgery, \\ University of Colorado Medical Center, Denver, Colorado
}

Wimu the advent of the tratment of human renal homotransplants by immunosuppressive drugs (Murray of al. 1962), many such kidneys have now functioned for several months (Hume et al., 1963; Murray of al. 1963; Starz ot al., 1963; Woodrutr et al., 1963); and several have

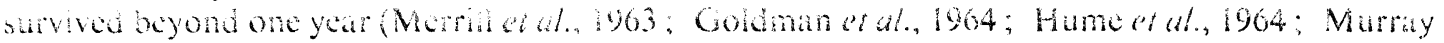
it al. 1904; Starzl et al. 1964; Dunea et al., 1965). Most of these transplants, even those between non-identical wins. have at some time during their stay in the recipient undergone one or more episodes of rejection. Recentiy serial biopsies have shown that acute fibrinoid necrosis of the vasculature of the transplant, with or without much celfular infiltration, may ocur during these crises (Porter et al., 1964 b). Further, even after treatment has apparently hated or reversed the rejection process, the vascular lesions may progress to fibrous intimal thickening with narrowing or obliteration of the interlobular arteries (Porter et al., 1964 b). It is not known how frecuently this progression occurs in transplants that survive a rejection episode. If tibrous intmal thickening is a common event then many of the renal homotransplants functioning to-day are likely to fail within a few years from ischæmic damage.

In this paper the pathological changes in thirty-seven human renal homotransplants from the Denver series are analysed with two main objects in mind. Firstly, to try and assess just how common vasculonecrotic lesions are in transplants that are clinically in a rejection phase; secondly, to determine how many of the transplants that survive such an episode show residual vascular damage.

\section{MATERIALS AND METHODS}

Between 24th November 1962 and 30th March 1964, seventy-live human kidneys were homotransplanted at the University of Colorado Medical Center: of these seventy-two came from living and three from cadaveric donors (Table 1). By ls1 June 1965, in thirty-nine instances either the patient had died or the transplant had been removed surgically because of failure to function or some other complication. Thirty-seven of these kidneys were examined and it is upon this material that the present report is based.

Each kidney was irasplanted into either the feft or right iliac fossa and the ureter molamed nino the bladder. In one of the cadaveric cases (CD3) two kidneys were transplanted at the sume operation, one mo each thite fossa: this patr of kidncys is counted as one carnshat in Table 1 . In eight patients. after the primary homotransplant or heteromoppian had failed a second kidney was inserted into the opposite iliac fossa and the priminy tanspiant removed. Case LD57, however, was an exception in that the first transplant, which never functioned. was left in the recipient. The period of ischemia each kidney underwent is siown in Tables It. IV and VI. In all cases except LD5, LD7 and LD43 bilateral nephrectomy and spiencetomy were performed at or before the time of transplantation. In LD5 neither of the putciits own kidneys was cemoved; in LD7 the right kidney was not removed until seventythree days after renat transplantation and in LD43 left nephrectomy was never performed. In 
awhor to this treament iow patenis (LD4, LDS, LD9, and LDI1) underwent thymecomy haten to eighy-ive days before renal homotransplantation.

At the patents were treated wh 6-(1-methy-4-ntro-5-imidazoly) thiopurne ("mand"), arang one 10 nineten days before ransplantation, in a dosage of 3 to $8 \mathrm{mg}$. per $\mathrm{kg}$. per day. On the day of surgery and for the first three days after transplantation the dosage was increased to 6 to $15 \mathrm{mg}$. per $\mathrm{kg}$. per day, but after this the dosage was reduced to 3 to $6 \mathrm{mg}$. per $\mathrm{kg}$. per day and regulated daily according to the total white cell counts in an attempt to avoid the production of severe leukopenia. In most of the patients steroids were withheld until the onset of rejection, but in nine patients (LD4, LD46, LD56, LD57, LD59, LD61, LD62, LD64, and SD3) prednisone 30 to $100 \mathrm{mg}$. per day was started two days before transplantation and administered continuously thereatter.

\section{TABLE $\mathbf{j}$}

Number of Kidneys Homotransplanted, Recipients still Alive and Transplants Exammed Pathologically in the Denver Serics

Outcome by ist June 1965

Kidneys Homotranplinted oetween 24 th November 1962 and 30 h varch 1964

75

72 hom living

donors

64 primary renal transplants

8 secondary

renal

trans-

plants

2 into patients who had previous primary baboon renal heterotransplants
6 into patients who had previous primary human renal homotransplants

ifrom cadaveric donors

6 into patients who had previous
primary human renal
homotransplants

75
Pationts

Failed and
Replaced
by Second

Failed and
Replaced
by Second

Failed and
Replaced
by Second

Transplants

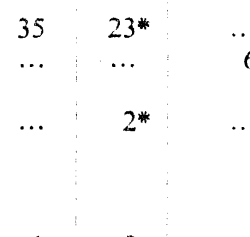

$\begin{array}{l:r}1 & 5 \\ & 3 \\ \cdots & 33\end{array}$

36 $\ldots$

$\cdots$

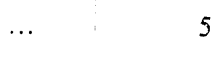

$\cdots$

(
22

3

37

* Permission for necropsy refused in one case.

When rejection was recognised, presnisone 150 to $400 \mathrm{mg}$. per day was given. Aclinomycin C. 200 10 400 micrograms intravenously, was also started and repeated every five to seven days. in the of the putients one or more courses of local $X$-irmatiation were given to the transplant. Each conte consisted of three or folu doses of $150 \mathrm{rgiven}$ every other day. Once reversal of the rejection phase was achieved prednisone was slowly reduced to a maintenance dose of 10 to 20 mas per day.

Matera fon the kidney tansplants was staned routinely with hamatoxylin and eosin, periodic aci Schfi ragent (PAS), Weigert's for clastic lissue counter-staned with hematoxylin and ba Geson. phoro-Maliory 5, Martus yellow-scarlet-blue (MSB), Mallory's phosphotungstic acd homoxyln (PAH), and mothyl green pyronin. Other special stains such as Sudan 3 and Masson 4,4 (Lendrum e' al., 1962) were lised when indicated. 


\author{
RLSULIS \\ The thiry-scven renat homotransplants felt into rour main groups:- \\ 1. Those from patients who were in a rejection phase. \\ 2. Those from patients who died after one or more rejection episodes had been recognised \\ and apparently treated successfuliy. \\ 3. Those from patients who had not at any time experienced a clearly recognisable clinical \\ episode of rejection. \\ 4. Those which either did not function or developed some complication necessitating their \\ early removal.
}

Transplants from Patients who were in a Rejection Phase.--Fifteen kidneys were examined after their removal from patients who were in or just starting to recover from a clinical episode of rejecion.

The ofs ot ejecton was assmed when, ater a period of normat renai function, the patient becunte vigurc and developed hypertension and hud retention, followed shortly afterwards by fever, tachycardia protenuria, elevation of the blood urea nitrogen (BUN) and creatinine, depression of the creatinine clearance $(\mathrm{Cr} C \mathrm{Cl})$ and urinary sodium excretion, swelling and tenderness of the ransplant, and sometimes by the appearance of lymphocytes in the urine (Starzl et al., 196.3). The development of this synurome varied in rapiefiy from a few hours to many days and Was not atways compleie. When the second episode of rejection occurred in transplant LD10, which had been functioning for more than seven months, the appearance of signs and symptoms was insidious and it was dificult to be ertain about the day of onset (Staral et al., 1964).

The clinical course of all the recipients in this group and, in those who died, the cause of death and some of the post-mortem findings, are listed in Table 11 . Two of the renal homotransplants had come from cadaveric donors (CDI and CD2) and one was a second transplant (LD29); the others were pimary renat homotransplants from living donors.

Gross Appearances.- Most of these renal homotransplants were enlarged, the mean weight being $241 \mathrm{~g}$. with a range of 148 to $350 \mathrm{~g}$. (The kidneys of the normal adult man weigh from 125 to $170 \mathrm{~g}$. each; those of the female weigh 115 to $155 \mathrm{~g}$. each.) The capsule was usually thickened, and in all but one of the cases stripped easily leaving a smooth cortical surface which in five of the transplants was speckled with petechial hæmorrhages. When cut the cortex was pale and bulged; in two of the kidneys the medulla was deeply congested. A few of the transplants showed tiny cortical areas of infarcion. The main renal vessels were patent, and in all except LD35 the ureters were unobstructed. In this hatter case there was blockage of the ureter with debris at its junction with the bladder. and a rupture $1 \mathrm{~cm}$. in diameter on the anterior wall of the pelvis. in another patient, LD61, the ureter had been re-implanted six days before the patient's death because of obstruction at the ureterovesical junction. The ureteric walls were thickened in the majority of the tansplants in this group.

Miroscopical dpporances (Table 111 )..... Glomeruli. - No striking changes were present. Twe cases showed sligh thekening of the batsement membranes of the tult capillaries by PAS-

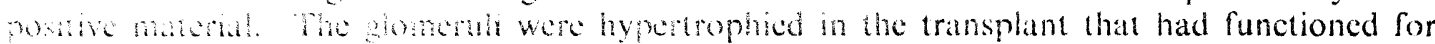

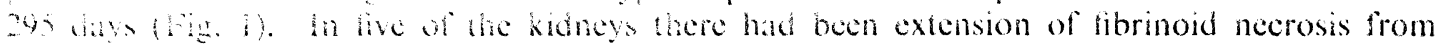

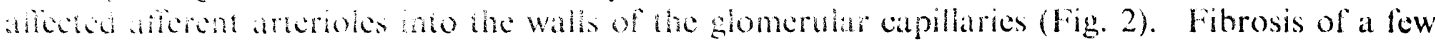
turts an priglomerulat tibrosis were presen alone or together in six of the transplants. Only one ane showed hypeplasia of the juxtaglomerular body with increased granularity of the fukgomewar cols.

Thbule-. Whasprad cech tubular necrosis whin active regeneration of the lining epithelium and cass of proten and entebris was seen in four of the transplants. Patchy tubular damage was gesent in tive otners. Aymphocytes were found in the lumen of a few tubules, but only in 


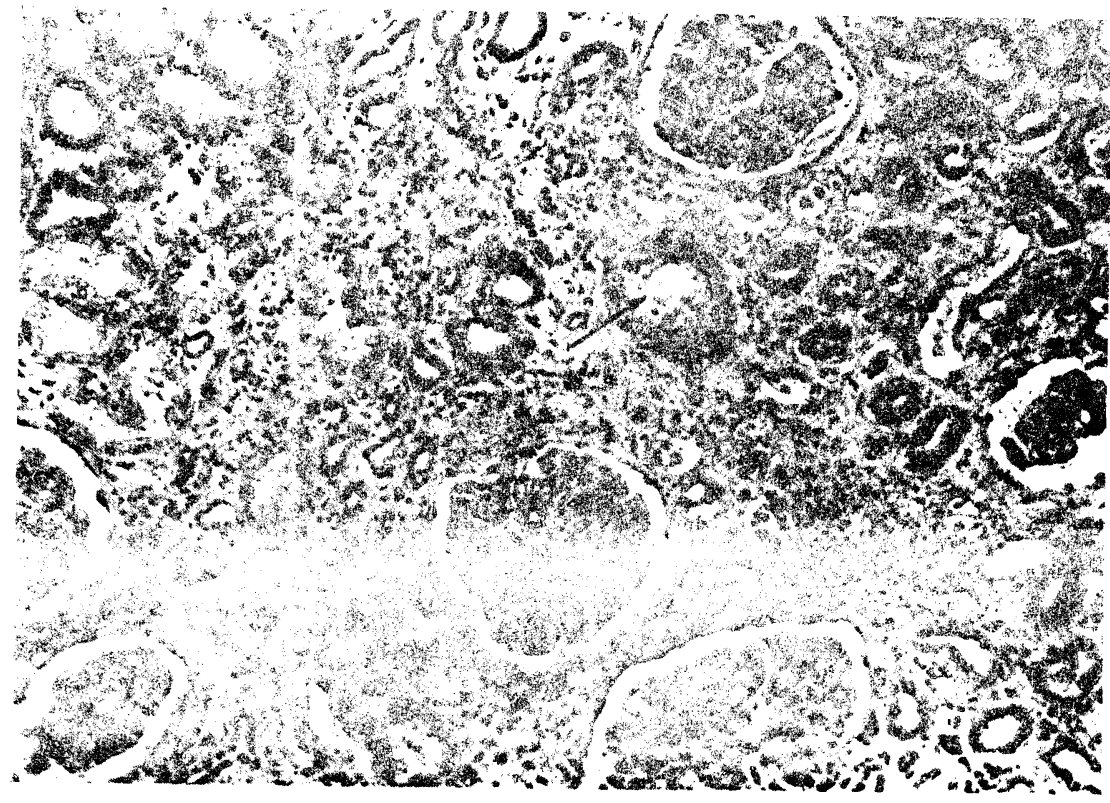

Fik. I

Ronul homotranspiant rom patien LDio who died at 295 days in a rejection episode which hadi started sndy-seven days previously. The glomeruli are hypertrophied, many of the moules ...e atrophe and the inerstitum shows hbrosis, some oedema and a few small foci of infitrating lymphoid celis. There is ribrous obliteration of an interlobular artery (arrow). (H. \& E.) $\$ 50$

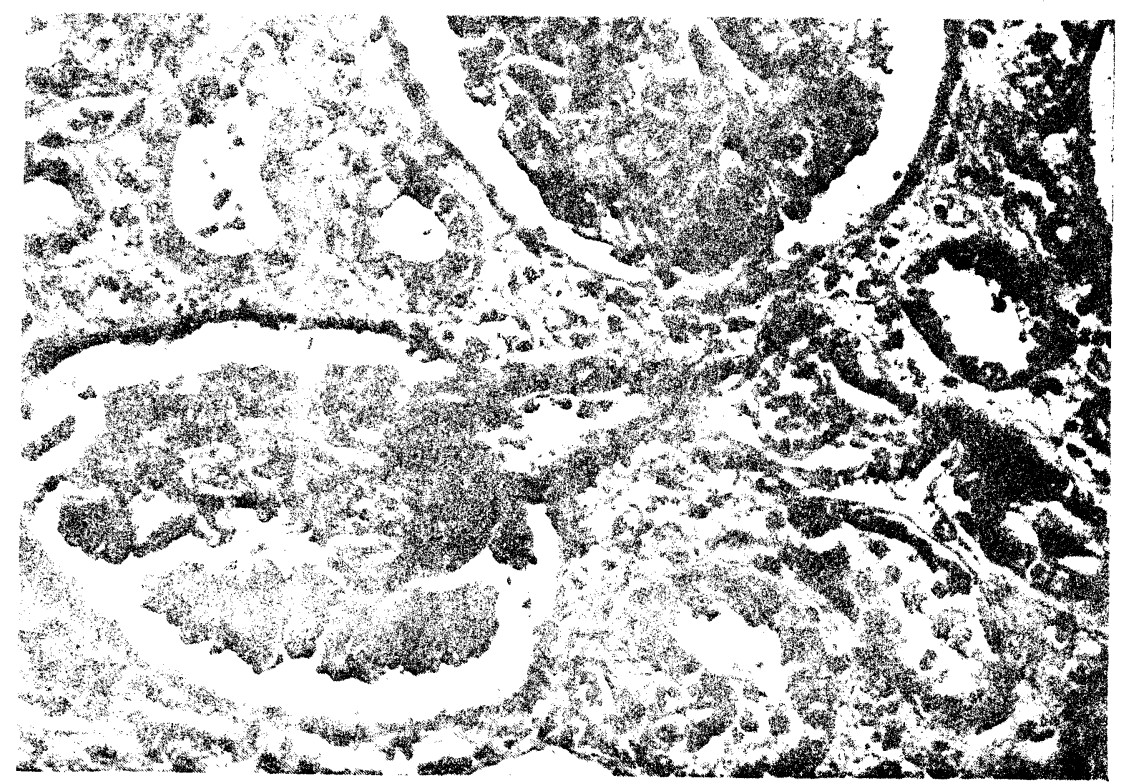

Fili. 2

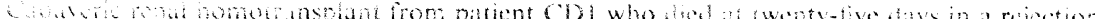

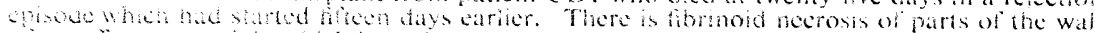

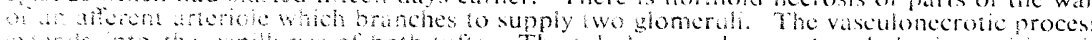

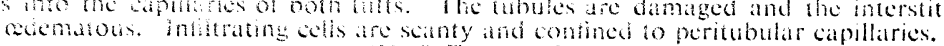

(11. \& E, $\quad 400$ 


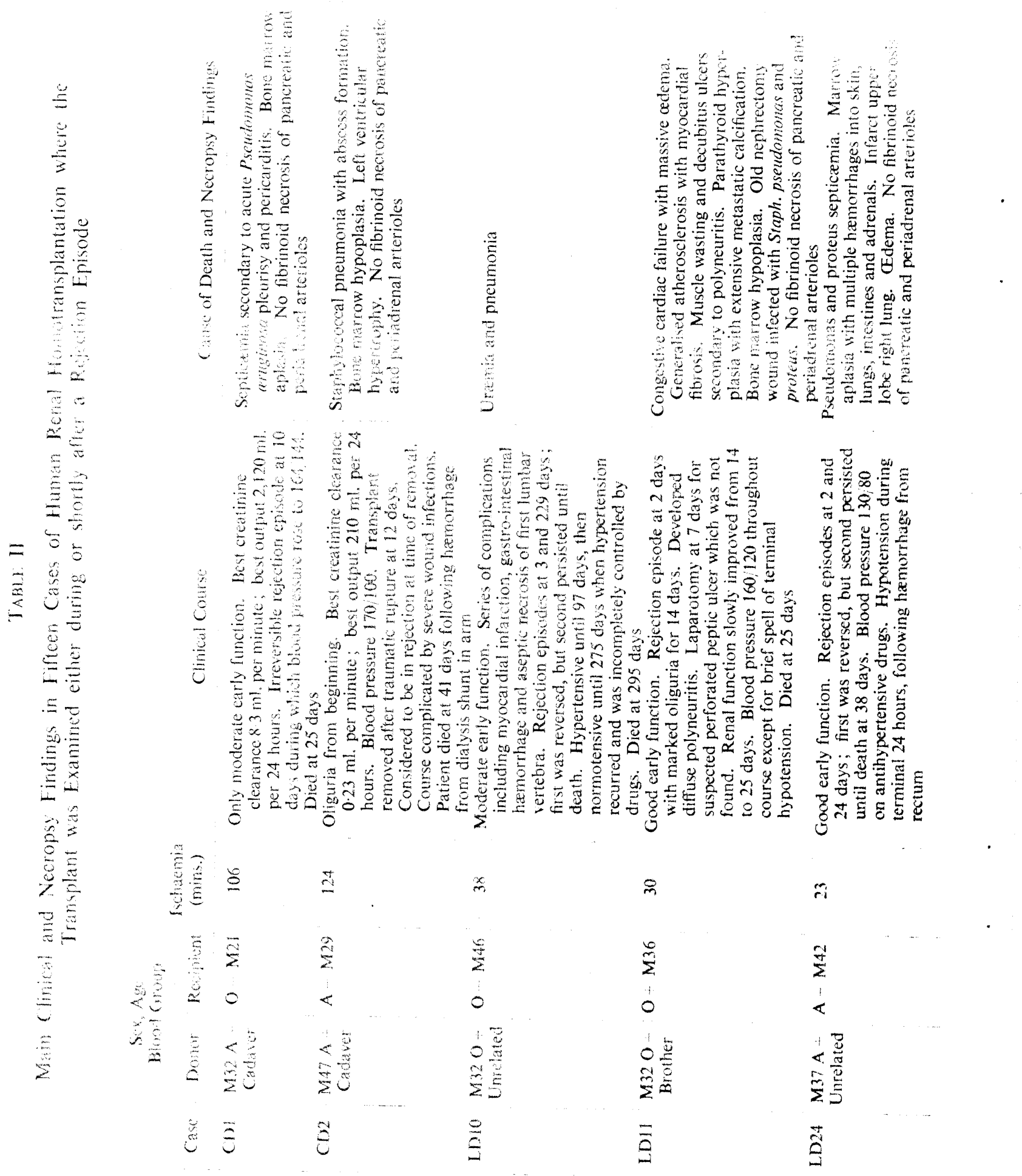



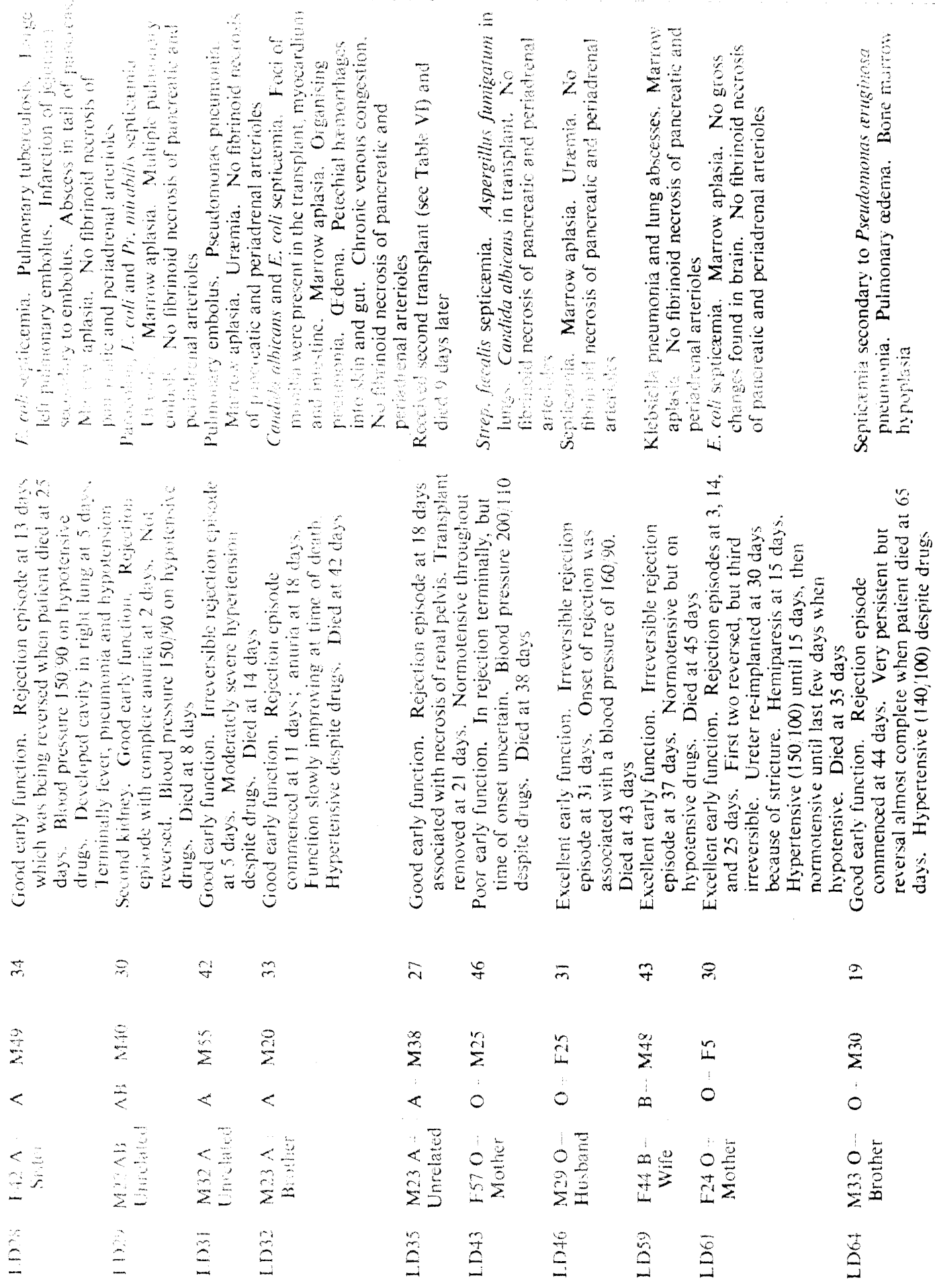


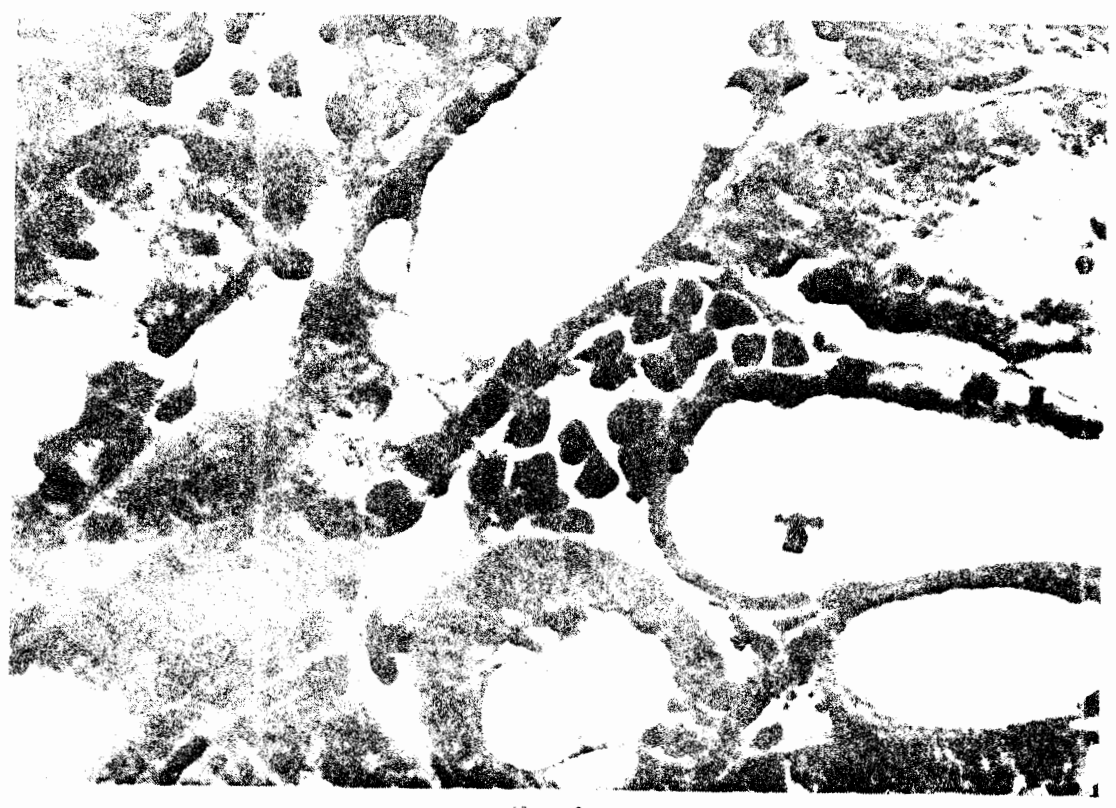

Fici. 3

Renal houotransplam whels was removed surgicaliv from patient $1 . D 35$ at twenty-one day becatise of necrosis of the pelvis. Rejection had started three days previously. A group of adjacent tubules are danaged. (H. \& E.), 500 .

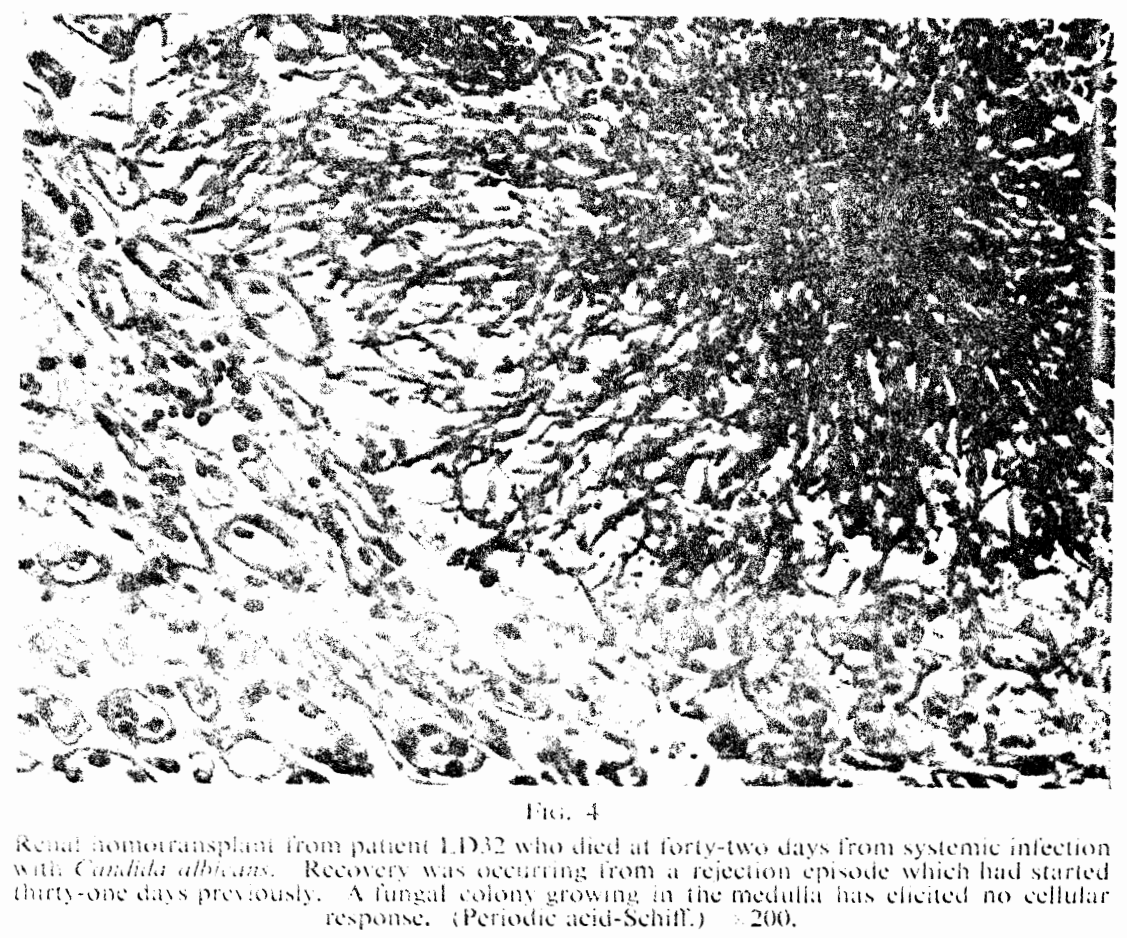


PATKOLOGY OF RENAL HOMOTRANSPLANTS

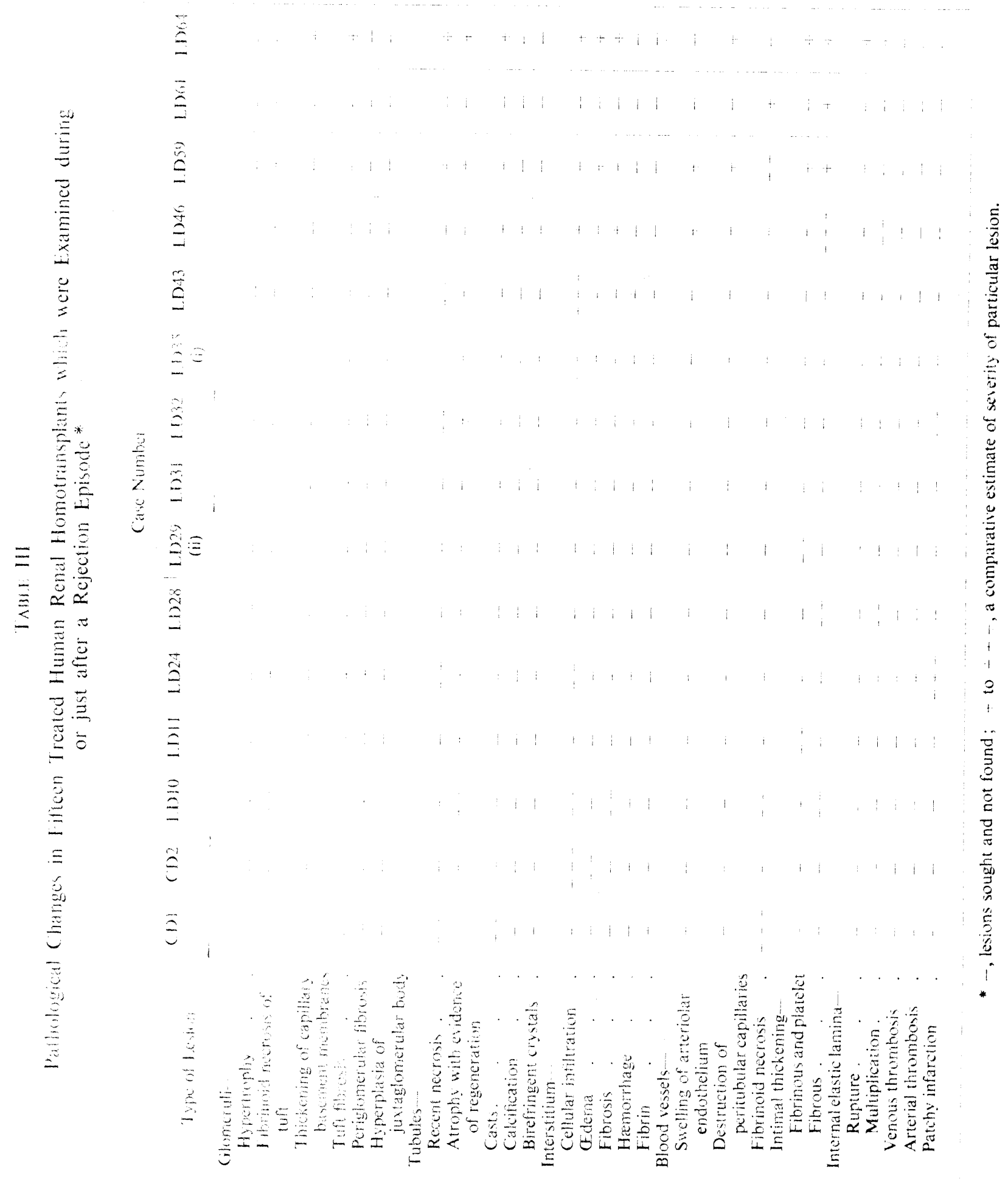


those cases with cubular damage und interstitial celluar inmitration. Birefingent calcium oxalate uysuils were present in six of these kidneys.

Intrestitium.-Cellular intitration was present in all but two of the cases: ahthough heavy th three it was generatiy ligh (Fig. 1) and consisted of occasional foci of small lymphocytes, plasma cells and larger celis with py:oninophilic cytoplasm, a large pale nucleus and prominent nucleolus. Often the cells were confined to peritubular capillaries (Fig. 3). Mitoses were not seen. OEdema was present in nine of the kidneys (Fig. 2) and there was interstitial fibrosis in six of the eight transplants which survived thirty-six days or longer (Fig. 1). Small hæmorrhages and collections of fibrin in the interstitium often accompanied arteriolar fibrinoid necroses. Monilial lesions were seen in two of the iransplants. In patient LD32, who had systemic infection with Candida albicans, the lesions consisted of necrotic areas containing budding forms centrally and hypha peripherally but no cellular response (Fig. 4). Fragments of hyphe of the same fungus were found in case LD43 surrounded and partly engulfed by giant cells.

Blood Vessels.-Foci of hbrinoid necrosis were seen in the walls of afferent arterioles and incerobular arteries in tweive of the fficen homotransplants (Fig. 2). The damage was most widespred and severe in CDI, a cadaveric kidney in which transplantation was from a donor who was blood group A rnesus positive to an $O$ positive recipient. The vasculonecrotic process generatly involved the whole thickness of the arteriolar walls, but usually affected only the media and intima of the interlobular arteries. The vasa vasorum of arcuate and interlobular arteries someimes showed these same necrotic changes. Swelling of the endothelial cells lining the arterioles was present in six of the cases, and obvious destruction of peritubular capillaries in ten. Fibrin and platelet deposits on the intima of damaged interlobular arteries (Fig. 5) were seen in nine of ine kidneys and fibrous intimal thickening of these vessels in eight. This latter change was most severe in LD46 where many of the arcuate and interlobular arteries showed obliterative changes. In most of the vessels there was general thickening of the intima by fibroblastic tissue, covered on the luminal side by a thin layer of endothelial cells (Fig. 6). The intimal thickening was sometimes confined to oniy part of the circumference of the artery (Fig. 7); on other occasions it had calused complete obliteration of the lumen (Fig. 1). Deposits of fat of variable size were present in the deeper hayers of the thickened in ima immediately adjacent to the media (Fig. 7). Redupication of the internal elastic lamina was present in eight cases and rupture of the same layer in six (Fig. 7). All the vascular lesions were more frequent and severe where arteries divided and gave rise to small side branches. Thrombosis of occasional small veins was found in four of the transplants and of damaged interlobular arteries in three. Tiny wedges of cortical infarction were present in four of these cases.

Ure'ter and Pelvis.--In those cases where the ureter was examined the transitional epithelium showed areas of ulceration (Fig. 8). There was edema of the interstitial tissues and a focal, sometimes heavy infiltration with lymphoid and plasma cells. Swelling of the endothelial cells lining the small arteries and arterioles and fibrinoid necrosis of the walls of these same vessels (Fig. 8) with rupture of the internal elastic lamina was common. Fibrin and platelet deposition on the intima of affected vessels was also seen. In some, focal infarction and hamorrhages into the ureteric interstitial tissues and into the peripelvic fat had occurred. These changes were prominent in the first transplant from patient LD 35 where rupture of one of these infarcted areas in the peivis had necessitited removal of the whole kidney.

Transplants Examined some time after Reversal of a Rejection Fpisode.--Twelve kidneys came in patients whose hast clearly recognisable rejection episode had been clinically reversed 1400 to days prevonsiv. Four of these cases had survived two rejection episodes and another rwo had eneountered three such crises. The clinical course of these patients, the ultimate cause of their ceath and some of the post-mortem findings are listed in Table IV. All the renal homotransplants were from living donors; three were second transplants (LD19, LD23, and LDS7). 


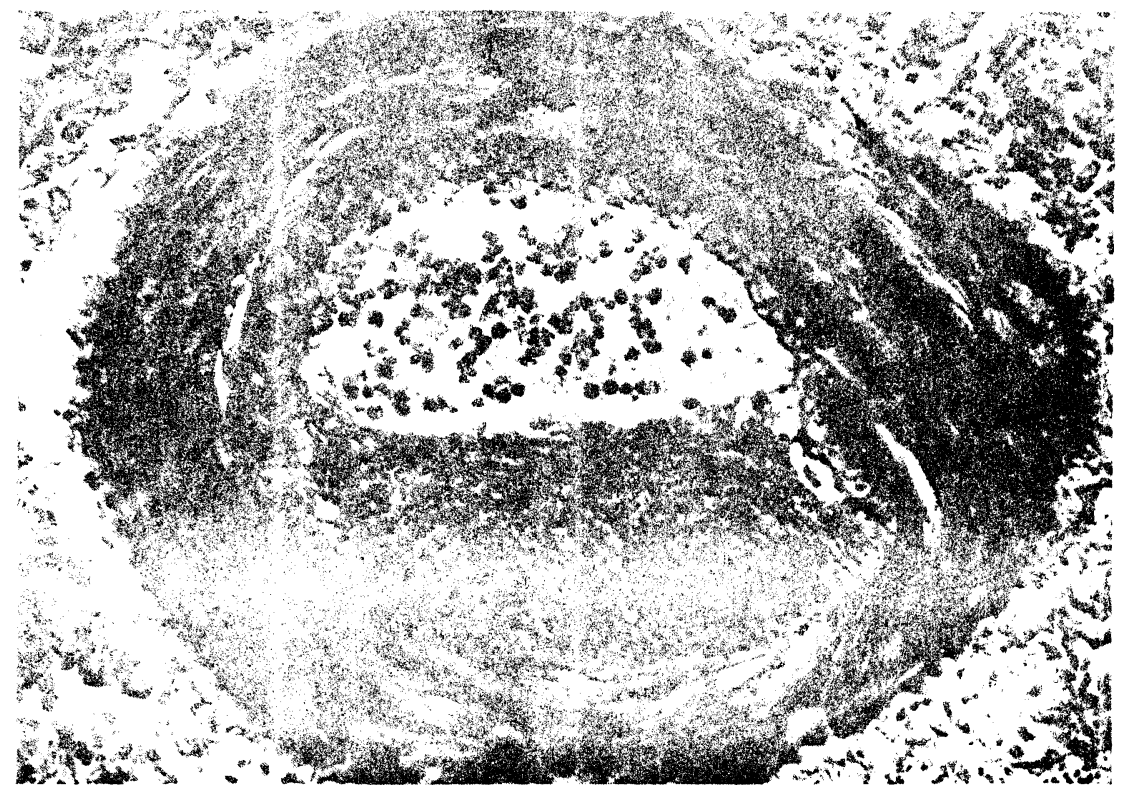

Fici. 5

Ren i homotranspian from patien LDil who died at twenty-five days whist recovering from rejection episode which had started twenty-three days belore. The intima of an arcuate artery is thichened ecentrically by a meshwork of fibrin and platelets.
(Lendrum's Martius yellow-scarlet-biue.) $\times 200$.

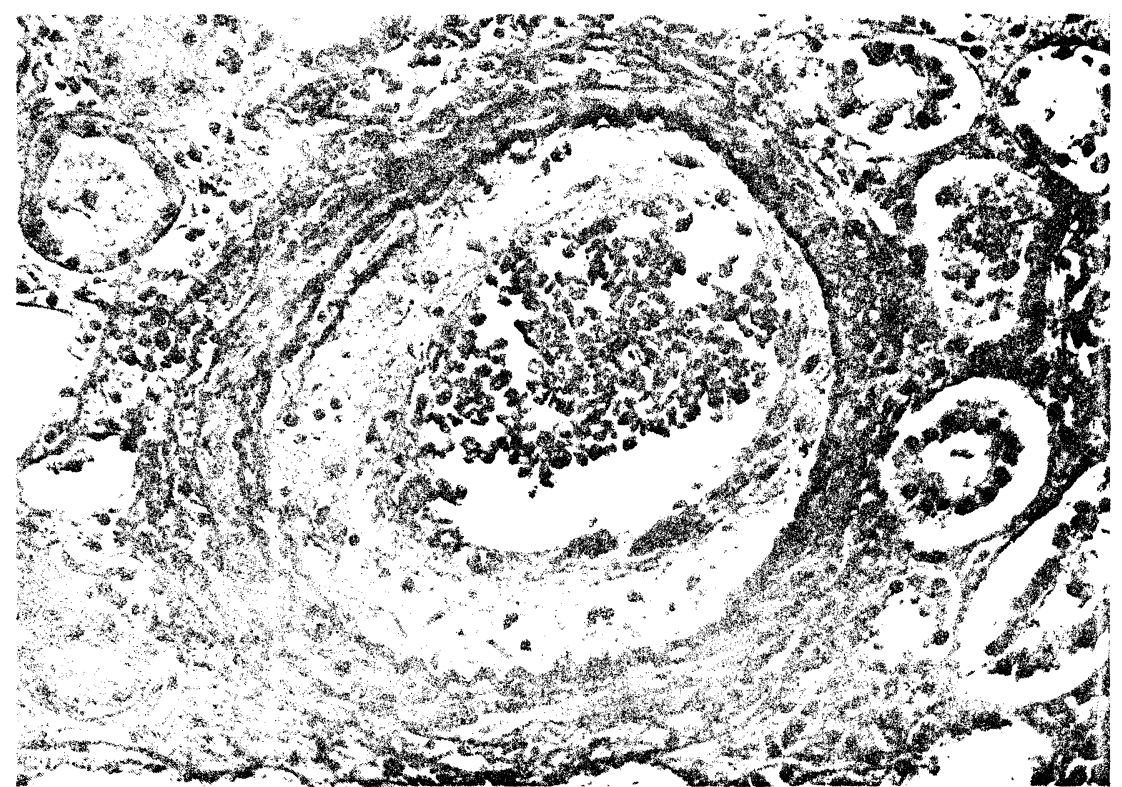

$$
\text { Fici. } 6
$$

Rend homotansphan from patient $2 D$ D 46 who died at forty-three days in a rejection enisode wheh hati sturted inelve days previously. An arcetste arfery is narrowed by conceniric tibrow intimal thichening. (Glastic van Crieson.) $\times 180$. 


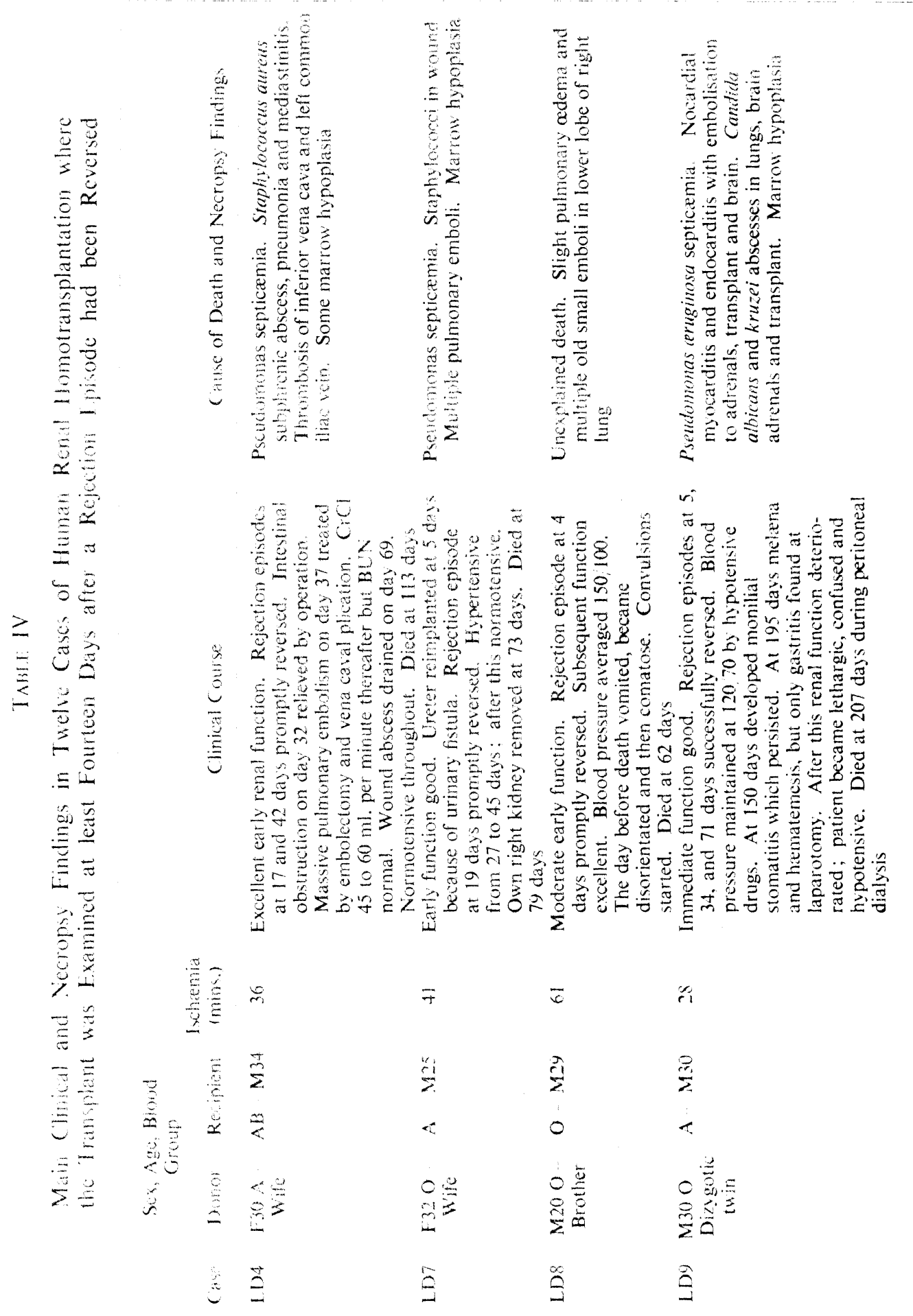



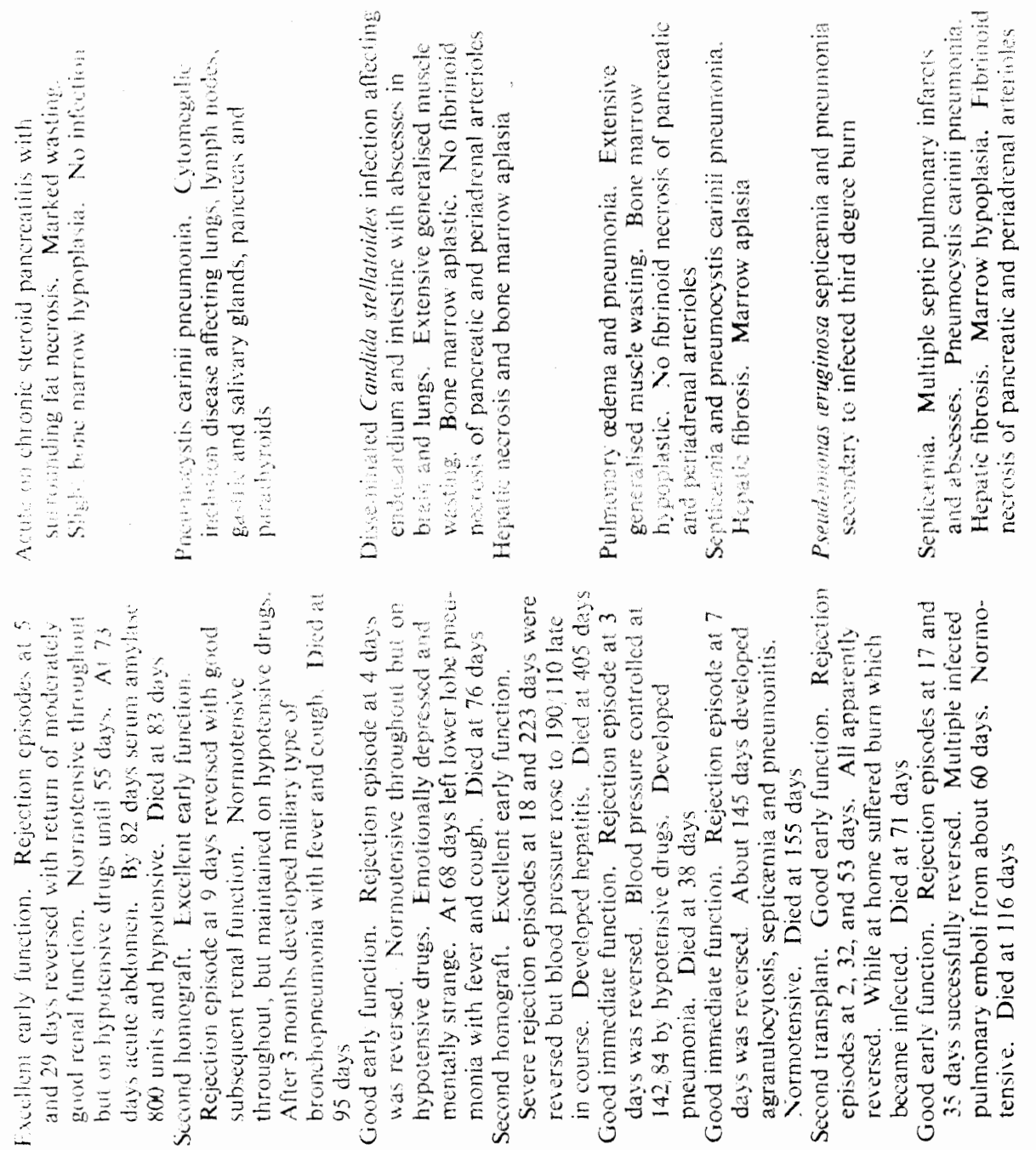

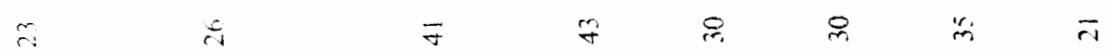

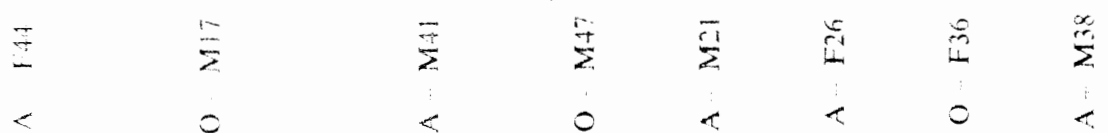

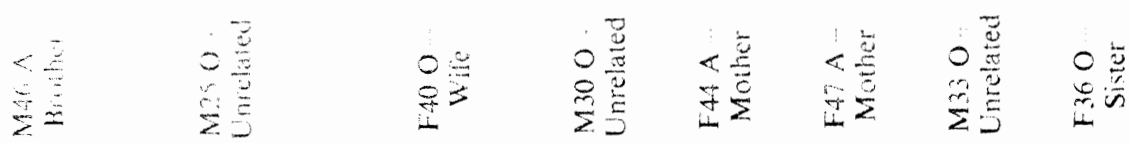

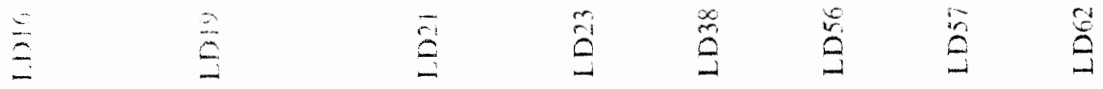




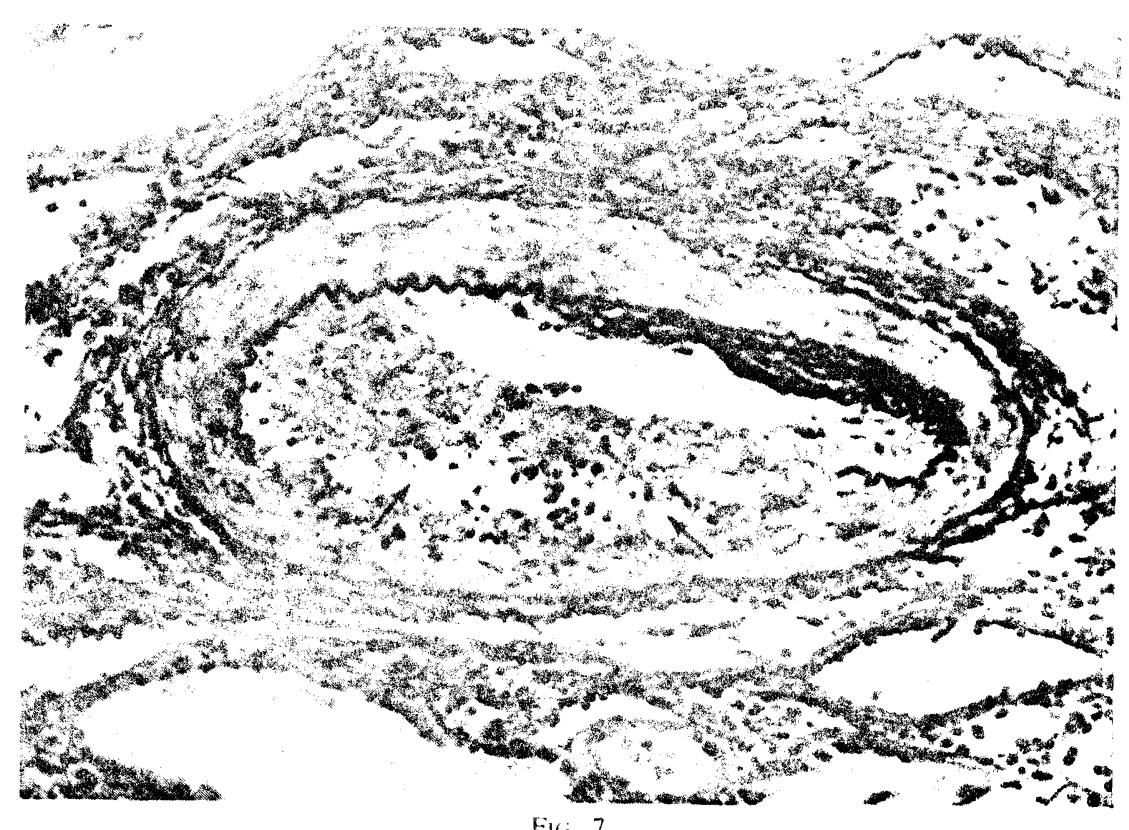

Renal homotransplani from patiens LD46 (see Fig. ()). An interlobular artery is greatly nurrowed by cceentric tibrous intimal thickening. The internat elastic lamina is ruptured over the intimal plaque: there is multiplication of the elastic opposite this areat. Fat spaces (arrows) can be seen in the deep layers of the theckened intimat adjacent to the internal clastic layer. (Elastic van Gieson.) $\times 300$.

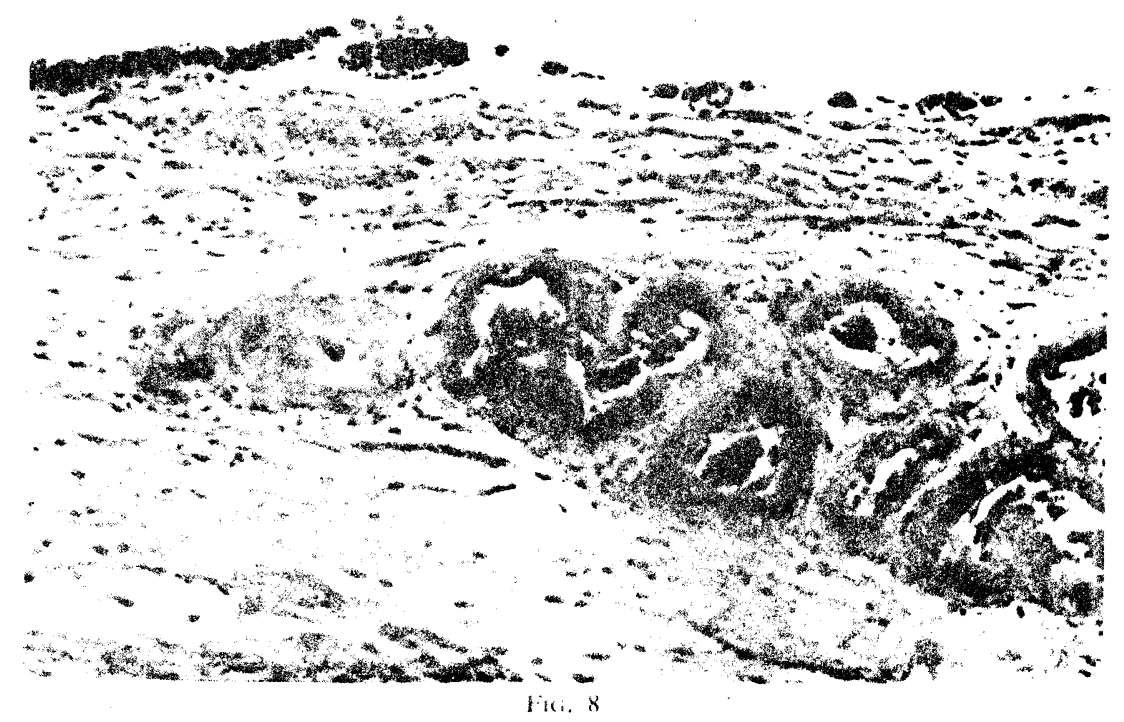

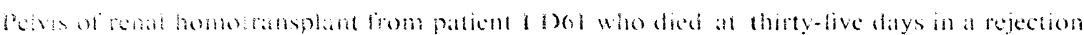

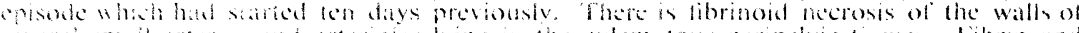

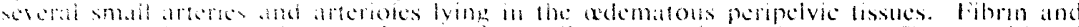

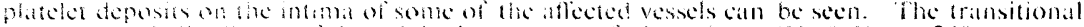

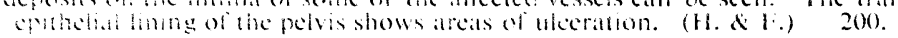




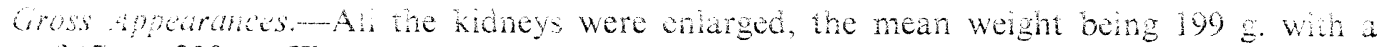
ango of 78 to $250 \mathrm{~g}$. The capsule was thickened and stripped easily in all but case LDI9, where

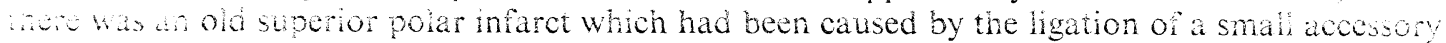
and at he the of transplantation. The subcapsular surface was smooth, the cortex pute ane the medula reduish-brown. In patient LD4, where plication of the inferior vena cava had been performed following pulmonary embolectomy, the renal and right iliac veins and the lower part of the inferior vena cava were completely thrombosed, but in the other eight cases the renal vessels and their anastomoses were free from any obstruction. The ureters were unobstructed.

Microscopical Appearances (Table V).-Glomeruli.-Hypertrophy of the glomeruli was a cature in aight of the transplants. In one kidney there was a PAS-positive thickening of the tuft capillary basement membranes; in two others occasional tufts were fibrosed and there was periglomerular fibrosis. Two of the transplants showed hyperplasia of the juxtaglomerular body with vacuolation and increased granularity of the cells in the walls of the afferent arterioles.

Tuhulex.-. Tubular damage was present in eight of these kidneys. In four it was recent nerows afecting predominanty the proximal convoluted tubules; these transplants all came from

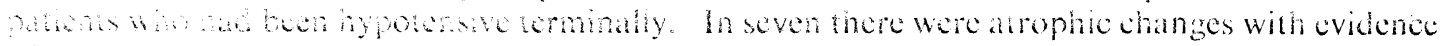

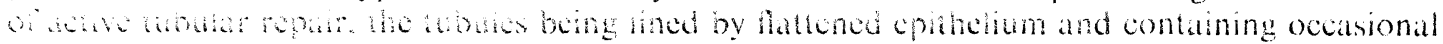

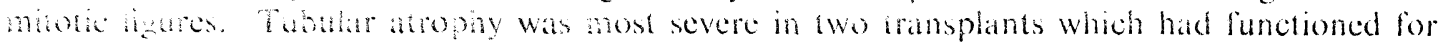

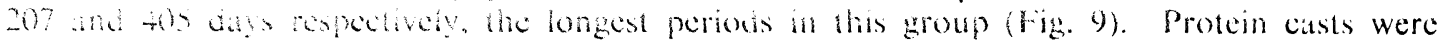
pesent his of these transpants, crystats of ealesum oxalate in four and patchy calcification within whular colls in tive.

Intryminn.- In eigh of the twelve transplants there was a very light, focal, cellular intitrution thig. 10\%. Otten the cells were confined ro peritubular capillaries. Most of the cells were smat tymphoyes and phama cells, but there were a few other larger cells with pyroninophilic cytopasm. Gema was present in oniy two cases; interstitial fibrosis was present in six (Fig. 9). In patient LD9 scittered Candida hypha and Nocardia were present with no surrounding cellutar reaction.

Blood Vessels.--Fibrinoid necrosis was present in the arteriolar walls of three of the twelve transplants, and swelling of the arteriolar endothelial cells in only one. Seven of the twelve kidneys, however, showed intimal thickening of some of the interlobular arteries. In one of the transplants the new intimal layer consisted only of fibrin, platelets and a few lymphocytes; in iwo it was fibrous; in the other four both types of thickening were present. Multiplication of the internal elastic lamina of intellobular and arcuate arteries was present in nine of these kidneys; rupture of the same layer was present in only three. Thrombosis of the small intrarenal veins was presen in three of the transplants, including the case where renal vein thrombosis was noted grosily.

Creter and Pelvis an those cases where the areter was examined the transitional epithelial thing was wen thm and in places absent. There was an increase in submueosal fibrous tissue and stantw of smikn material separated the masele bundles. In two the arteries supplying the treter showed throts intmat thickening and either duplication or rupture of the internal elastic liminiat.

Transhats tron Paticnts who hat mot developed Chical Lvidence of a Rejection Episode.--

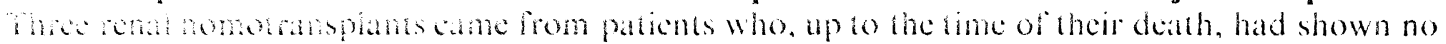

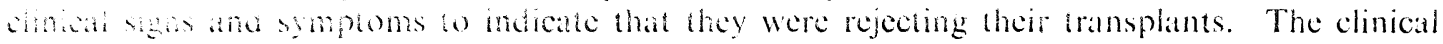

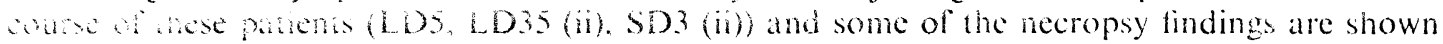

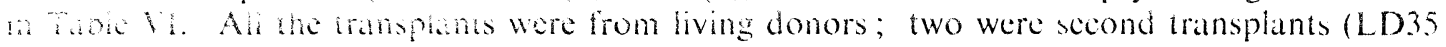
ansosit.

Ges thearames.- Two of these kidneys appeared nomal and weighed 150 and $180 \mathrm{~g}$.

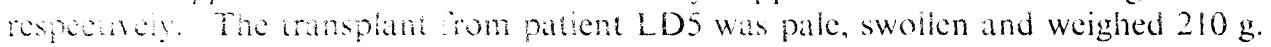

Afrescoplat Appearances (Table VII).... Glomeruli. - The only abnormatities were in case 


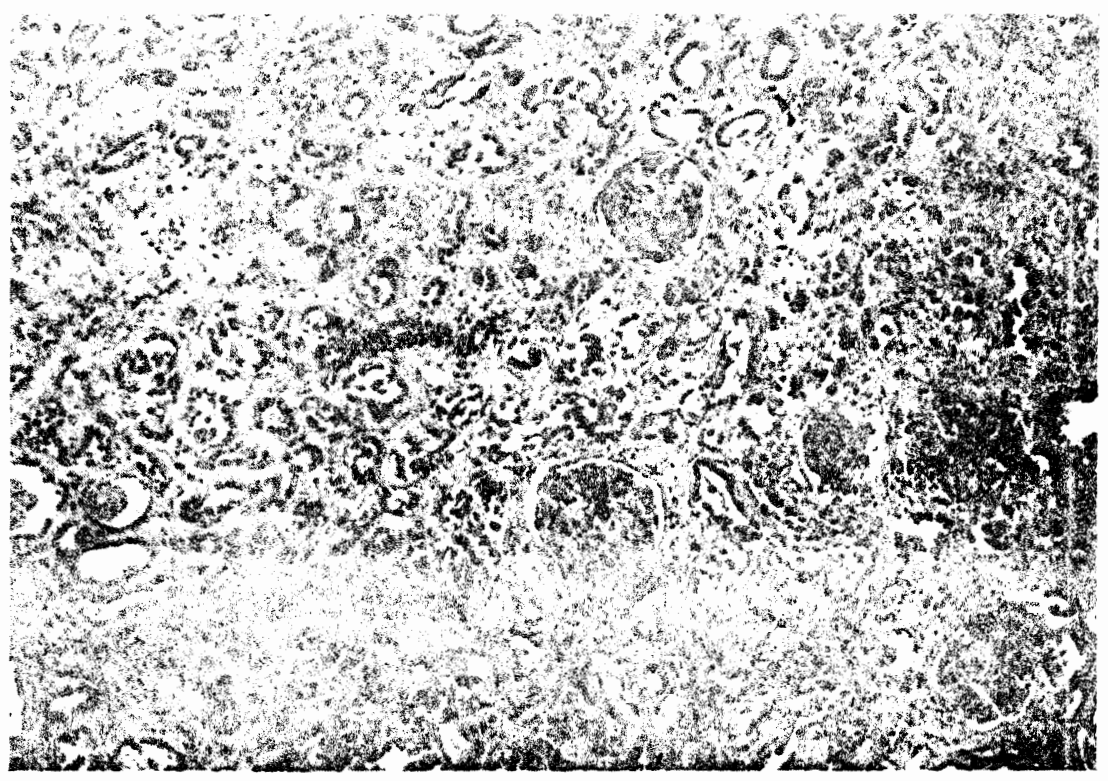

Kin. 9

Renat homotransplint from patent LD9 who died at 207 days from septicemid, systemic nowardidis and eandidiasis. Rejection episodes at five, thirty-four, and seventy-one days had been sucessfully reversed. There is widespreal tubular atrophy and interstitial fibrosis, but very little ceilular infiltration. Many peritubular capillaries have been destroyed. (H. \& E.) $\times 140$.

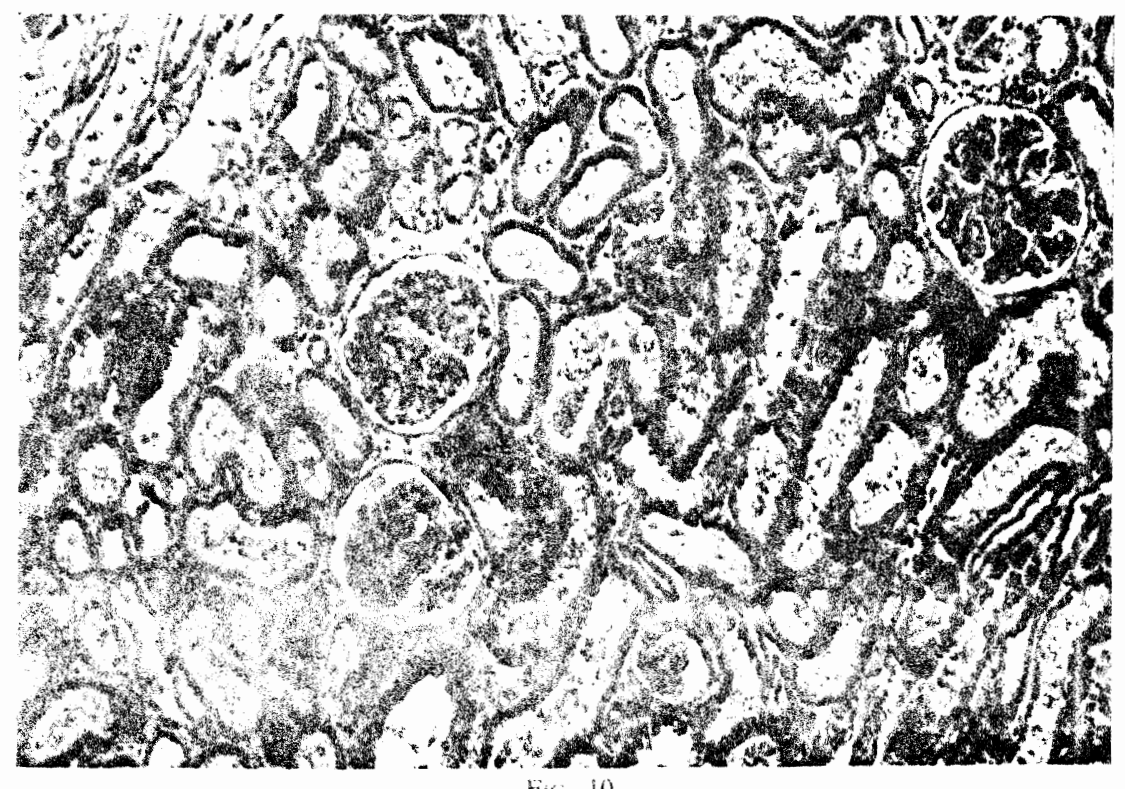

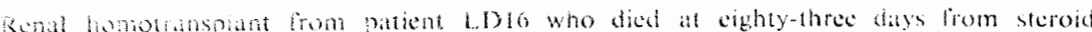
pancreatis. Rejection cpisodes at five and twenty-mine days had been successfully reversed. There are a very fow rafiltating cells, all conined to peritubular cap 


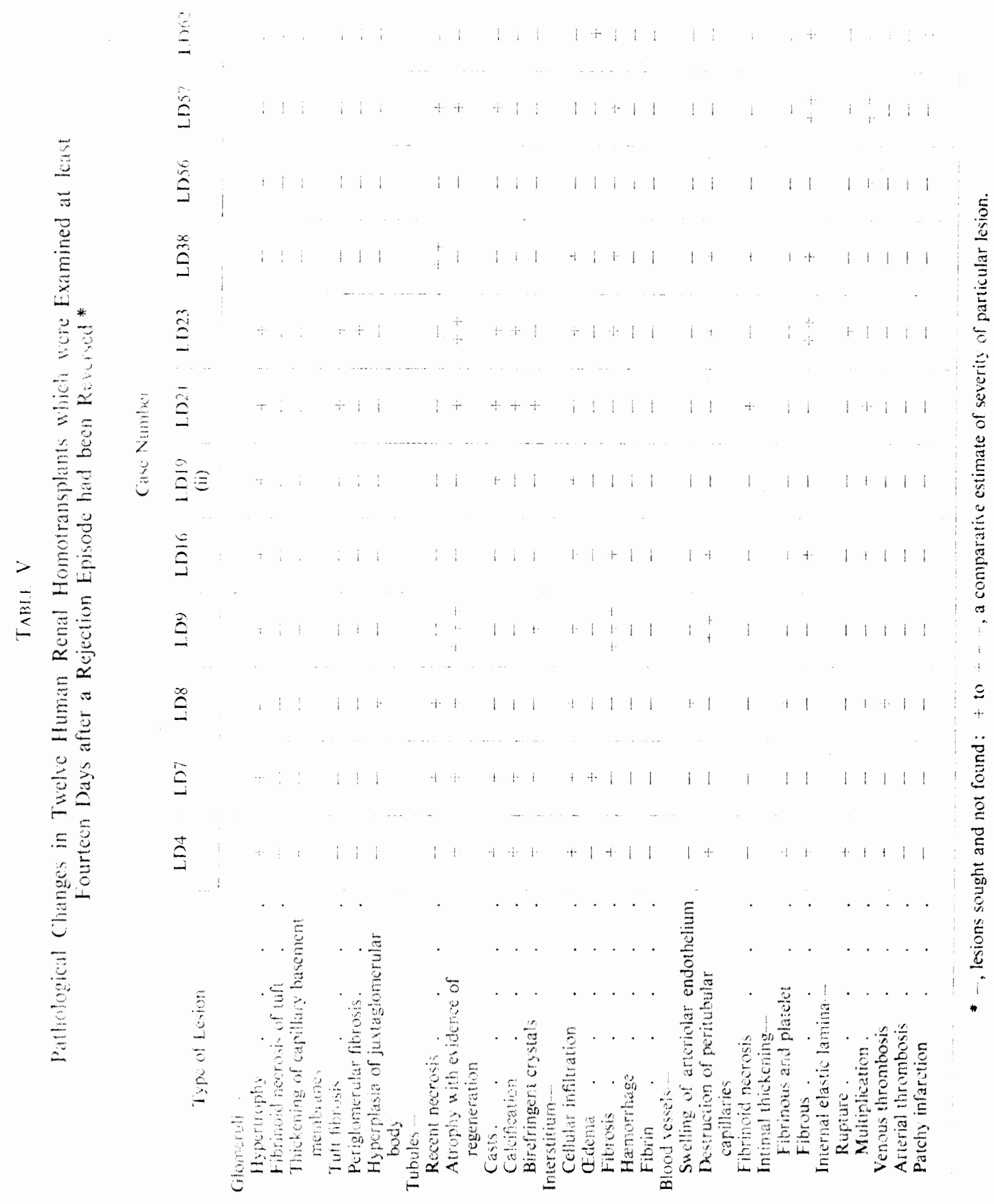


SD3, whe some of the glonerul showed focal thickening of unt capillary basement membranes by mueria whoch stwined with Masson 44/41 as old nbrin (Lendrum et al., 1962).

Thouks.-in LD5 where severe hypotension had been a post-operative complication thus was widespread tubular necrosis with evidence of repair. Less severe older tubular damage was present in SD3. Many birefringent calcium oxalate crystals were present in LD5.

Interstitium.-Two of the homotransplants contained several foci of infiltrating lymphoid and plasma cells and interstitial æedema was present in two.

Blood Vessels. - Only the renal transplant from SD3 showed vascular changes. There was patchy replacement of arteriolar walls by material staining as old fibrin with Masson 44/41 and plugging of the lumens of a few of these vessels with similar material. Several of the interlobular arteries showed either fibrinous and platelet intimal thickening, or, more frequently, fibrous thickening of this layer, with damage to the internal elastic and narrowing of the lumen.

Transplants which either did not Function or Developed some Complication necessitating their Eary Removal.- The seven transpiants in this caterory could be subdivided into five small groups acouding to the man factor causing fallure of the transplant or death of the recipient Tables $V$ and Vhi).

1. Techinical Failure.--In LD57, at the time of transplantation, one of the two veins draining the kidney was ligatured. After completion of the vascular anastomoses, however, it was found that the remaining vein was obstructed by the artery which crossed it. By the time this situation had been rectified the transplant had probably been at body temperature without venous drainage for about 120 minutes. The transplant never excreted urine but it was not examined until seventyseven days later. By that time it weighed 190 g., showed complete hemorrhagic infarction and there was old thrombosis of the main renal artery and both renal veins.

2. Ischicemia.-The first kidney to be transplanted into patient LD29 was supplied by two small arteries. The anastonosis of these to the recipient vessels produced a greater delay than usual and the transplant was ischæmic for eighty-four minutes. As it did not excrete urine it was removed at forty-eight hours and replaced by another transplant.

In the second case (CD3) both kidneys came from a man who had died from a myocardial infarcl. The left kidney was ischemic for 137 minutes and the right for 215 minutes; further, the donor had been hypotensive before death. Both kidneys failed to excrete urine and the patient died at four days.

Ali these transplants were pale and slightly swollen; the cortex was widened and the corticomedullary junction blurred. The vessels were patent and the ureters unobstructed. Microscopicaliy, there was massive recent tubular necrosis, affecting particularly the proximai part of the nephron (Fig. 11). The lumens of the tubules were filled with casts of protein and cell debris. There was evidence of active repair in the form of mitoses among surviving proximal tubular cells and the hining of tubules by new flattened epithelium. The interstitium was adematous and contained scattered foci of small lymphocytes, plasma cells and occasional polymorphs, chiefly in reation to severely darnaged tubules. The cellular infiltrate was heaviest in CD2. The glomeruil were nomal in the transplant that had come from the living donor, but in the other case there was periglomerular fibrosis and a few fibrotic glomeruli. The cadaveric kidneys also showed tbrow intmat thickening of the incrlobular and arcuate arteries.

3. Bhod Groat) Incompathility.-.Two kidneys, which were incompatible on the basis of ABO bood groups. When transplanted into group $O$ rhesus-positive recipients became eyanotic whim a Gew minutes and falled to excrete urne. The first kidney (LD/9) came from a group A Wuste whor and the seomd (LD23) was from a group B positive donor. Both transplants were renoved whin thre bours of their insertion. They showed great distension of the afferent menows wherthrocyles and sludging of these same eells in the giomerular capillaries. There was incrstha ortema and hemorthages but no cellular inflitration.

+. Hemorhages.-- In case LD49 there were technicat dificulties at the time of transplantation 
whon resuhed in the kidney bens ischemic for fify-eight minutes. Flow of urine hom the nomotansplant did not begin for two hours, but after this there was a daly excretion of 2 to 3 his. However, the urine was heavily contaminated with blood. The hematuria persisted wat, even ater thee explorations, no cause could be found: at four days the kidney was removec. Examination of the gross specimen showed blood in the pelvis but no bleeding point could be identified. Microscopically there were foci of proximal tubular damage and many crystals of calcium oxalate in the lumens, but no evidence of blood or pigment in any of the nephrons.

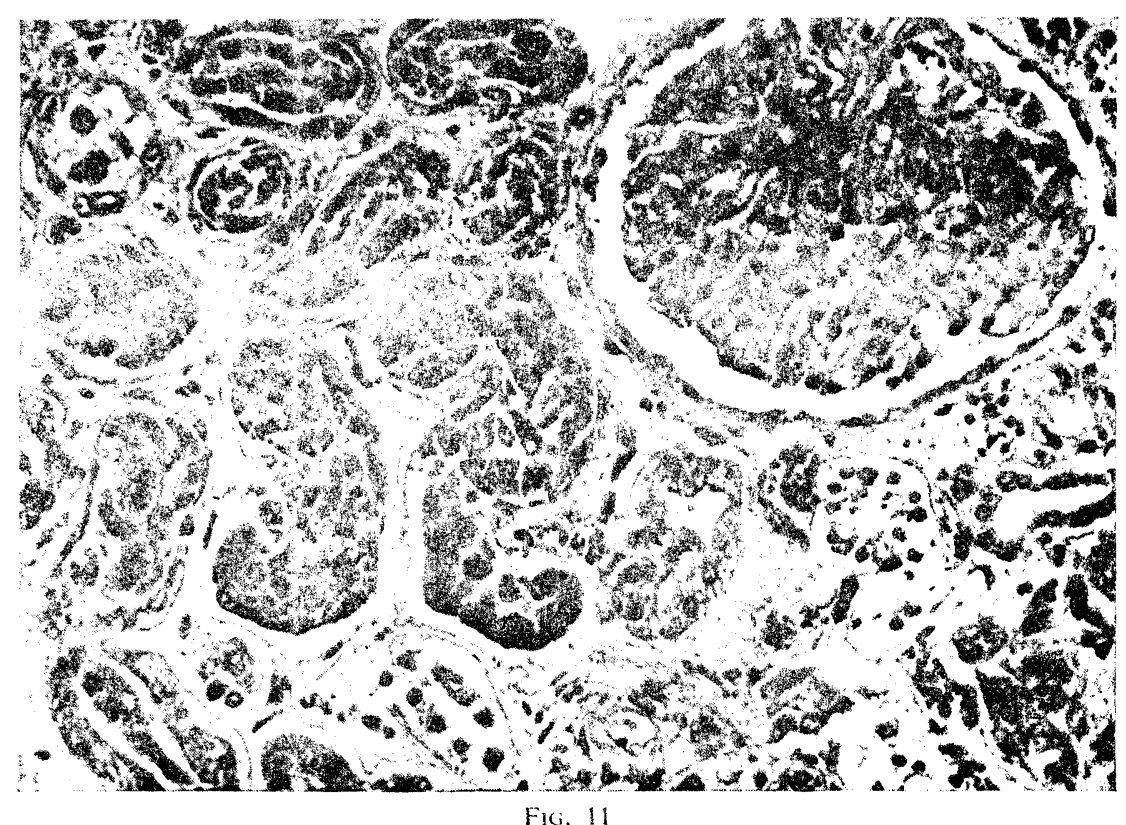

Renal homotransplant which was removed surgically from patient LD29 at forty-eight hours because it had failed to excrete urine. There is marked tubular necrosis, affecting particularly the proximal parts of the nephrons, some interstitial adema and occasional infiltrating host celis. (H.\& E.) $\times 400$.

There was no interstital edema, only minimal cellular infilt ration and no evidence of inflammatory changes in the pelvis of the aransplant. In the peripelvic fat there was a band of hemorrhage and several small arteries were necrotic. There were many tiny foci of ulceration in the pelvic transitional epthelium and hemorthage oozing into the pelvis had ocetrred over a wide area.

$\therefore$ Hedrolyte lmbalance.--One pationt (L.D26) died twelve hours after operation from hyomatrema and hyperkalamia during a massive post-operative diuresis in which urine output from the fansplant averaged $1.320 \mathrm{ml}$. per hour. The immediate cause of death was cardiac arresi. At hecropsy the homotransplanted kidney was a tittle swollen and pale. Mieroscopically the boute and marshinm apocared nomal, but some of the glomeruli were fibrosed and a few showed thows thekening of the capillary basement membranes associated with periglomerular thorosis. There was nyalinisation of the walls of occasional afferent arterioles.

\section{DISCUSSION}

Swelns of the endothelat cells hing arterioles and hbrinoid necrosis of the walls of these resses are now beng recognised as important features of the acute homogralt reaction in both human and canine renat homotransplants which have been modified by treatment (Parsons et al., 


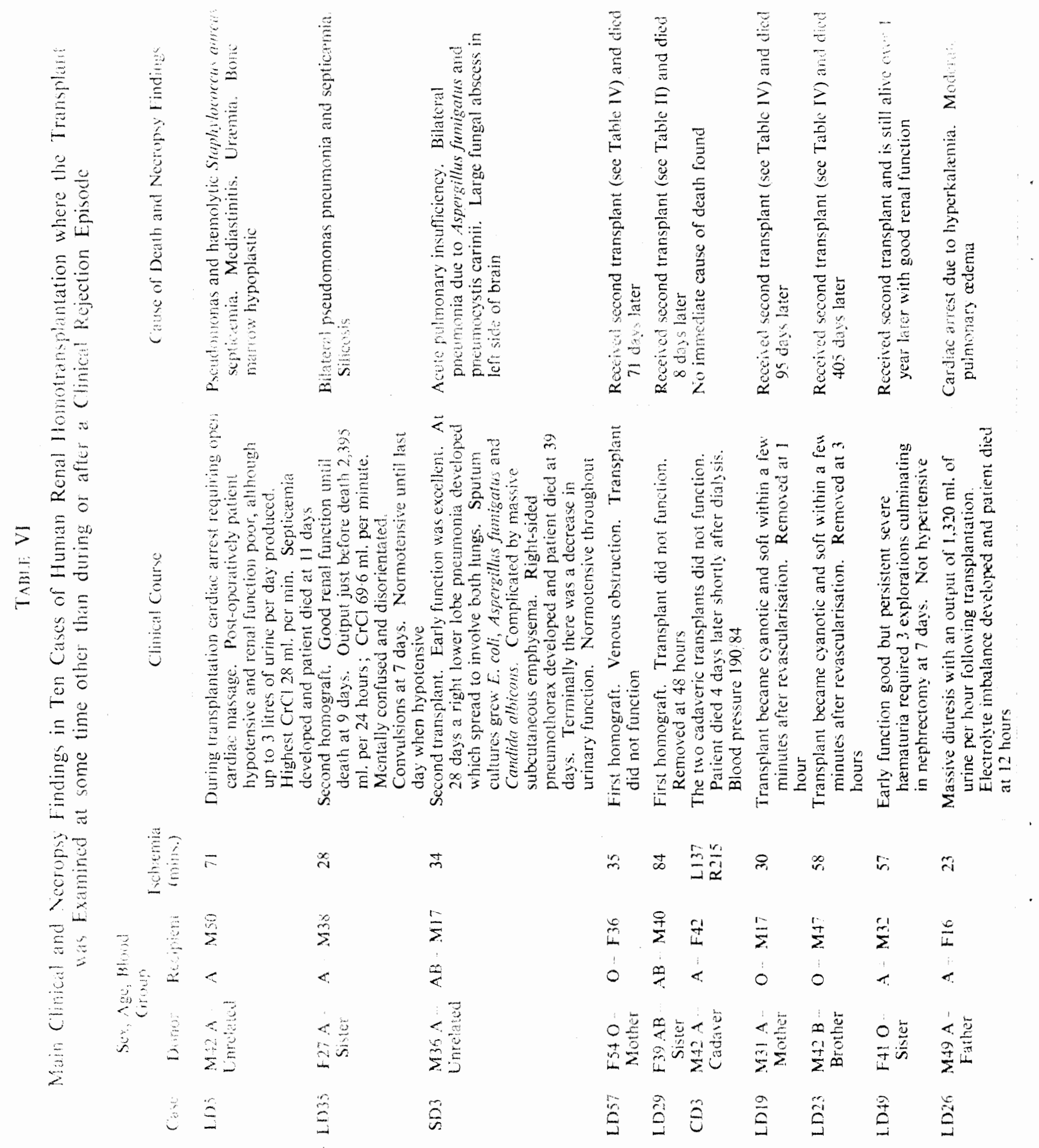




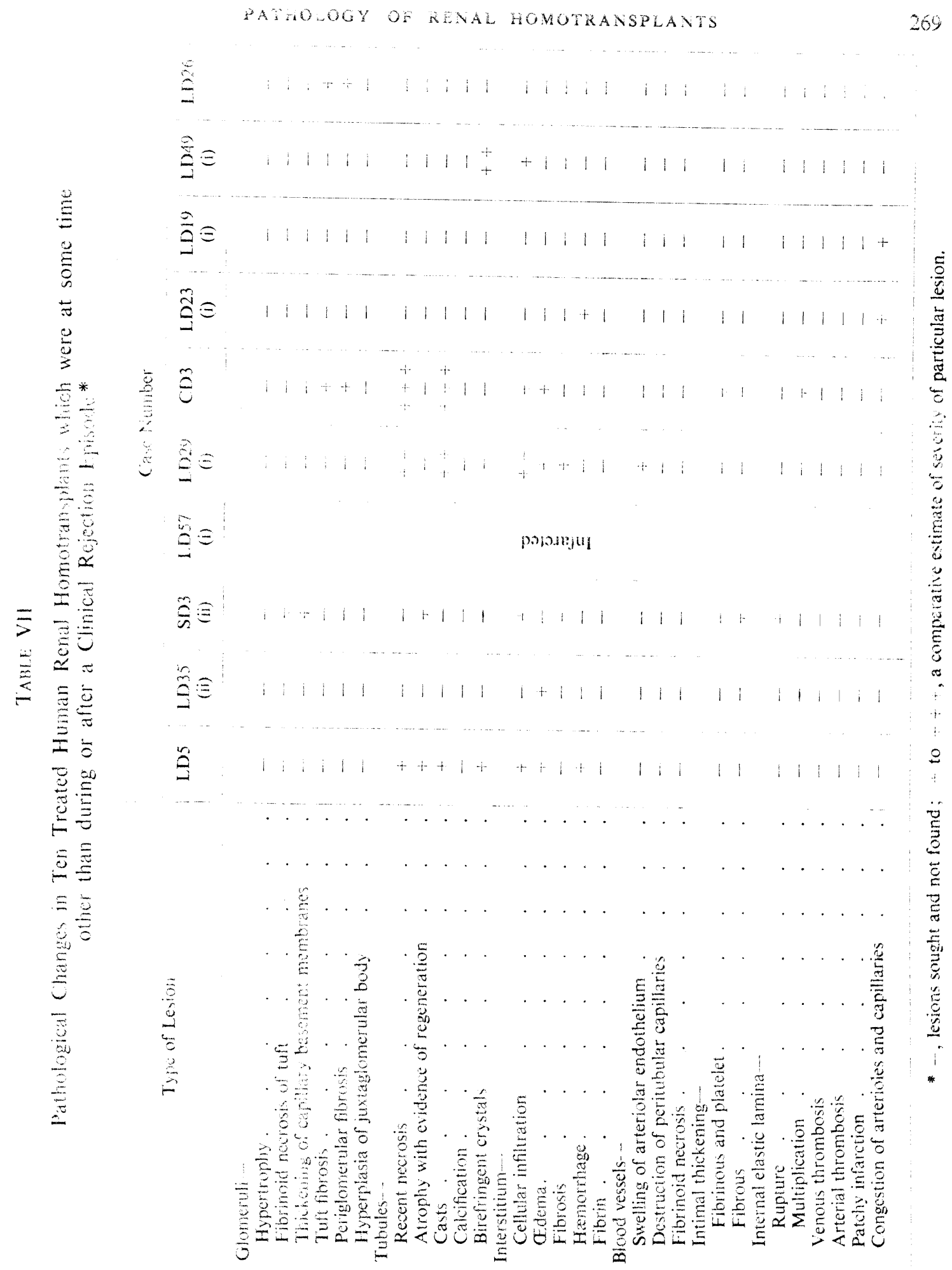


1963, Dempster ot al. 1964; Kincaid Smith, 1964; Porter et al., 1964a). In the present series. fiften transplants were examined at a time when the patient was either in or just reevering fron a clinica rejection episode. Forty per cent. of these kidneys (Table III) showed arteriola: endothelial swelling and 80 per cent. showed necrotic lesions affecting the afferent arterioles and sometimes the vatsa vasorum. Fibrinoid necrosis of the walls of interlobular arteries and fibrinoplatelet and fibroblastic intimal thickening in these same vessels were also common.

Becatise of the close resemblance between some of these lesions and those seen in malignant phase hypertension, the possibility has to be considered that the vascular damage we have deseribed resulted from exposure of the vessels of the transplant to a pressure higher than that to which they were accustomed. However, although many of the patients were or became hypertensive, the blood pressure in four patients (LD10, LD24, LD59, LD61) who developed florid vasculonecrotic lesions in their transplants was throughout controlled at normal levels with hypotensive drugs. Morcover, lesions were found in the renal transplant from one patient (LD35) who was not hypertensive at any time after transplantation. The damage was, therefore, not initiated by a raised blood pressure, but hypertension may have been a contributory factor when it reathe thgh lovels as, for example, in CDI where the diastole pressure was $144 \mathrm{~mm}$. Hg. That it can never have been a major factor is witnessed by the ack at necropsy of fibrinoid necrotic lesions in vessels elsewhere in the recipients' tissues (Table MI).

Neither can X-iradiation have been an important factor in the production of this vascular damage because only three of the transplants with lesions had been exposed to this treatment.

Ali the recipients were given corticosteroids, Imuran and actinomycin $\mathrm{C}$, but it is improbable that any of these agents played a part in the production of the vessel changes because vasculonecrotic lesions have occurred in renal homotransplants in both humans (Parsons et al., 1963) and dogs (Porter et al., 1964 a) treated with immunosuppressive drugs other than these. Even in normal untreated dogs, the arteries and atterioles within a renal homotransplant may show fibrinoid necrosis of their walls in the later stages of the rejection process (Simonsen et al., 1953).

In a previous paper (Porter et al., 1964 b) it was proposed that there are two important events which bring about failure of renal homotransplants. The first of these, disruption of peritubular capillaries (Kountzel al. 1963), seems to be a major factor underlying the rejection of untreated kidneys transplanted into normal recipients; it is mediated by infilt rating host cells, which perhaps carry cell-bound antibody. The second, endothelial swelling and fibrinoid necrosis of the walls of arterioles and arteries, is a relatively unimportant terminal event in the rejection of untreated renal homotransplants which is perhaps mediated by circulating antibody. It was suggested that when survival of the transplant is prolonged by immunosuppressive drugs, this humoral aspect of the host's response may assume greater importance, in that during a rejection episode circulating antibody is rapidly produced. The resulting antigen-antibody reaction occurring in or on the arteriolar wails would cause swelling of the endothelial cells, and might induce spasm of the smooth muscle in the vessel. Later fibrinoid necrotic changes would appear in the damaged wall. Such lesions, widespread in a transplant, could explain the alterations in water, electrolyte and creatinine excretion that occur in a rejection crisis.

If the rejection episode is halted at the stage of endothelial swelling of arterioles there should be complete return of the vesseis to normal. When fibrinoid necrosis of arterioles has occurred bealing with resals in hyaline changes in the walls of these vesseis: if there is secondary thrombosis there th the thbrosis of the associated glomerulus. Once the damage has involved the interlobular atreries and homal change has induced deposition of platelets and fibrin, ending the rejection phase wit no prevent healing with replacenent of the intimal deposits by fibroblasts. This pogiession has been cleaty demonstrated by suceessive biopsies taken from a human renal hombtamstant atming and after treatment of a severe rejection episode (Porter et al., 1964 b). Wher the vessel whil has been appreciably weakened by the necrotic process, compensatory Horom numb thickening will asso contribute to the narrowing of the lumen. If necrosis is intiats? wdespread in the hager anteries, the healing process can produce obliterative collagenous 
Swons throghout the renal arteriat tree and many examples of this conotion have now beth

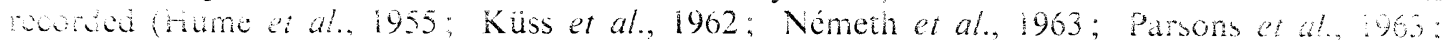

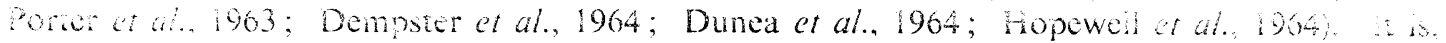
nowever, not known how frequently fibrous arterial narrowing is likely to arise as a comphcatoni of a rejection episode which has been treated and apparently completely reversed with return of good renal function.

In the present series twelve transplants were examined after at least one rejection episode had been clinically reversed. Seven of these showed intimal thickening of interlobular arteries, but only in two were the lesions at all marked. Although this paucity of severe obliterative vascular lesions is encouraging, it should be noted that only one of the transplants was normal. A mild, focal cellular intiluation, tubular atrophy, and interstitial fibrosis were the other common changes. The tubuar damage might have been due to a nephrotoxic effect from chronic administration of Imuran, but it is more probable that peritubular capillaries were continually being damaged on a small scale by host cells which resulted in a focal loss of tubules. Most of

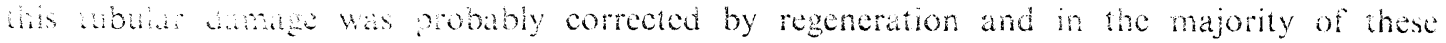
maspan ase was evende of active thbuar repar. The hree homograns which showed ameriola hbmoid necrosis were probably undergoing rejection which had nor been recognised cinically.

Durng recetion focd proximal tubular necrosis was often seen and was probably secondary to disruption of peritubula capillaries. In those transplants which survived a rejection episode but developed narrowing of the interlobular arteries, severe tubular atrophy was usual, based on simpic ischemia as occurs in cases of renal artery stenosis. Transplants which were deprived of a blood supply for long periods during the actual procedure of transplantation suffered, as would be expected. severe proxinal tubular necrosis.

In a few tansplants there was enlargement and increased granularity of the juxtaglomerular eells: changes which are ofien seen when kidneys are ischemic.

The glomerular and arterial lesions in the cadaveric transplant CD3 and the damaged artertolar " walls in LD26 were presumably present in the kidneys before they were transplanted.

Many of these renat homotransplants were enlarged. In those cases examined during or just atier rejection the increase in weight was almost entirely due to interstitial adema and cellular infleration foliowing damage to the fine vessels. In those kidneys which had existed for long periods in bilaterally nephrectomised recipients, compensatory hypertrophy was the main eause of the eniargement.

As would be expected the vessels of the transplanted ureters were also involved in the rejection process. Fibrinoid necrosis of the small arteries and arterioles was accompanied by focal infarction of the ureteric wall. Some of these changes have been previously well illustrated in a case described by Kuss et al. in 1962. A point of particular interest that emerges from this study is that if at the time of rejection, the ureter becomes blocked distally by debris due to tubular destruction restiting from the inirarenal vascular changes, then rupture of the necrotic ureterk of pelvic wall may ocur as happened in LD35.

Four of this series of thirty-seven renal homotransplants showed some thickening of the gimerutat tull apditary basement membranes. More severe lesions have been encountered by Hambares at (1963) in wo human renat homolransplants seven and fifteen months after opandi. Smitar thanges have been described in some of the transplants in dogs which have

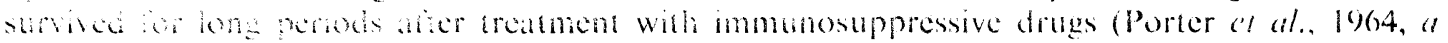
and ht. The canc kesons were thought to have resuled fom a combination of ischamia and

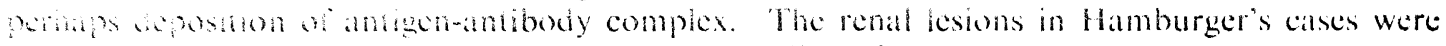

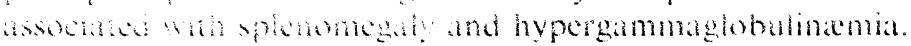

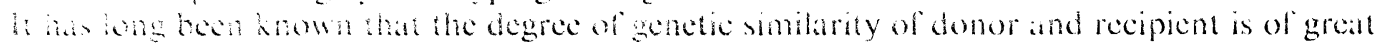
monetane when sonsidering the fate of homograts. This is borne out in the Denver series where maten (45.7 per cont) of the thirly-nine renat homotransplants that failed by Ist 
the 965 were from an unelated donor (cadaver, volunteer, wife or husband); wheres my tre (13.9 per cent.) of the thirty-six homografts still functioning at this the were rom such Gonors.

\title{
SUMIMARY
}

Pathological changes in thirty-seven human renal homotransplants are deseribed. All the patients had been treated with imuran, prednisone and attinomycin $\mathrm{C}$; ten had also received local X-irradiation to the transplant.

Fitteen of the transplants were from patients in a rejection phase. Most of these kidneys were enlarged because of interstitial odema and several were speckled with petechial hemorrhages. There was fibrinoid necrosis of afferent arterioles and interlobular arteries in twelve of the transplants, and the peritubular capillaries were disrupted in ten. Swelling of the arteriolar endothelial cells, fibrino-platelet and fibrous intimal thickening of interlobular arteries were also common. in most of the transplants there was a light infiltration with small lymphocytes, plasma colis and a tew larger pyroninophilie cells. Similar changes were present in the pelvis and ureter.

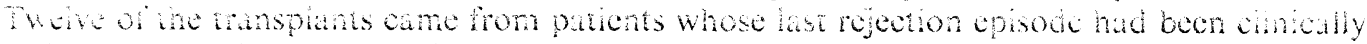
ceversed is to 117 days previously. All these kidneys were entarged becatuse of compensatory hypertophy. Seven showed some intmal thickening of the interiobular arteries and in three there was ibrinoid necrosis of arteriolar walls. Tubular atrophy, interstitial fibrosis and a light cellular infiltration were also common changes. Only one kidney appeared normal.

Three transplants came from patients who had not experienced clinical evidence of a rejection episode. One showed acute tubular necrosis due to prolonged ischrmia at the time of transplantation; one was almost normal; the third showed vascular lesions suggestive of old unrecognised rejection.

Seven transplants had either not functioned or developed some complication necessitating their carly removal. One of these was infarcted due to obstruction of the venous drainage; two showed massive acute tubular necrosis due to ischiemia; two, which were incompatible with their hosts on the basis of $\mathrm{ABO}$ blood groups, failed to excrete urine and showed distension of the arterioles and glomerular capillaries with erythrocytes; one bled uncontrollably from the pelvis; one came from a patient who died at twelve hours from hyperkaliemia and hyponatremia during a massive post-operative diuresis.

This work was aided by grants A-6283, A-6344, HE-07735. AM-07772, AI-01452, and OG-27 from the U.S. Public Heath Service, and by a grant from the Medical Research Council.

The necropsies on cases described in this paper were either performed or supervised by Drs Coral Cotierall, Doris Courington, Carol Ewing, R. B. Hill, J. Jamroz, D. W. King, D. M. Lang, Martha La Via, Elizabeth Macintyre, N. McGrath, J. C. Malisel, C. G. Massion, D. R. Meckin, H. B. Neustem, S. Ryan, and D. E. Smith. We would like to thank all these pathologists for making this study possible. We are particularly grateful to Dr D. T. Rowlands, who supervised some of the necropses, for his helpful co-operation throughout this study. Renditl

Expert assistance in preparing the sections and photomicrographs wals given by Miss Jane

\section{REFERENCES}

\author{
Dimste, W. J., Hakisin, C. V., and Shackman, R. (1904). Brit. med. J., 2, 969.

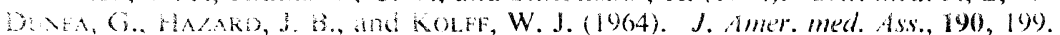

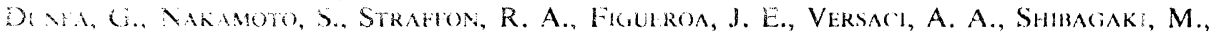 \\ and Kont. W. I. (1965). Brit.med. J., 1, 7.

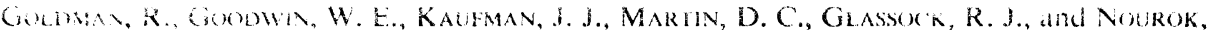

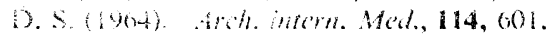

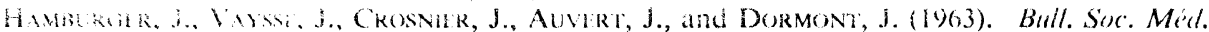 \\ Hip. Pari, 114, 225.
}


HOYWELL. J, CALVE, R. Y., and BESWICK, I. (1964). Brit. med. J., 1, 411.

Hume, D. M., Magee, J. H., Kauffman, H. M., Ritrenbury, M. S., and Proux, G. R. (1963). Antr. Surs., 158, 608.

Hume, D. M., Magee, J. H., Prout, G. R., Kauffman, H. M., Cleveland, R. H., Bower, j. D., and LEE, H. M. (1964). Ann. N.Y. Acad. Sci., 120 (1), 578.

Hume, D. M., Merrill, J. P., Miller, B. F., and Thorn, G. W. (1955). J. clin. Invest., 34, 327.

KinCAID-SMITH, P. (1964). Brit. med. J., 1, 178.

Kounrz, S. L., Williams, M. A., Williams, P. L., Kapros, C., and Dempster, W. J. (1963). Nature, Lond., 199, 257.

Küss, P., Legrain, M., Mathé, G., Nedey, R., and Camey, M. (1962). Rev. franç. Étud. clin. biol., $7,1048$.

Lendrum, A. C., Fraser, D. S., Slidders, W., and Henderson, R. (1962). J. clin. Path., 15, 401.

Merrill, J. P., Murray, J. E., Takacs, F. J., Hager, E. B., Wilson, R. E., and Dammin, G. J. (1963). J. Amer. med. Ass., 185, 347.

Murkay, J. E., Gleason, R., and Bartholomay, A. (1964). Transplantation, 2, 660.

Murray, J. E., Merrill, J. P., Dammin, G. J., Dealy, J. B., Alexandre, G. W., and Harrison, J. H. (1962). Ann. Surg., 156, 337.

Murray, J. E. Merriei, J. P., Hakrison, J. H., Wilon, R. E., and Dammin, G. J. (1963). Now Lith. M. Mrd. 268, 13 is.

Nemith, A., Pigki, G., Gá, G., Fazlikas, S., Altokjay, I., Sculthty, S., Balogih, L., and KARPAit, E. (1963). Orvosi Herilap, 104, 2017.

Parsoms, F. M., Markiand, C., Raper, F. B., and Fox, M. (1963). Brit. med. J., 1, 930.

PokTtr, K. A., CalNi, R. Y., and ZuKoski, C. F. (1964a). Lab. Invest., 13, 809.

Pokttr, K. A., Phart, W. S., Kenyon, J. R., Joseph, N. H., Hoehn, R. J., and Calne, R. Y. (1964 b). Am. N.Y. Acad. Sci., 120 (1), 472.

Porter, K. A., Thomson, W. B., Owen, K., Kenyon, J. R., Mowbray, J. E., and Peart, W. S. (1963). Brit. med. J., 2, 639.

Simonsen, M., Buemann, J., Gammeltoft, A., Jensen, F., and Jørgensen, K. (1953). Acta path. microbiol. scand., 32, 1 .

Starzl, T. E., Marchioko, T. L., and Waddell, W. R. (1963). Surg. Gynec. Obstet., 117, 385.

Starzl, T. E., Marchioro, T. L., Porter, K. A., Moore, C. A., Rifkind, D., and Waddell, W. R. (1964). Ann. intern. Med. 61, 470.

Woodruff, M. F. A., Robson, J. S., Nolan, B., Lambie, A. T., Wilson, T. I., and Clark, J. G. (1963). Lancet, 2, 675. 